\title{
Yield of Winter Oilseed Rape (Brassica napus L. var. napus) in a Short-Term Monoculture and the Macronutrient Accumulation in Relation to the Dose and Method of Sulphur Application
}

\author{
Mariusz Stepaniuk ${ }^{1}$ and Aleksandra Głowacka ${ }^{2, *(D)}$ \\ 1 STEPPOL AGRO, Łykoszyn 61, 22-652 Telatyn, Poland; stepaniuk.m@op.pl \\ 2 Department of Plant Cultivation Technology and Commodity Science, University of Life Sciences in Lublin, \\ 15 Akademicka Street, 20-950 Lublin, Poland \\ * Correspondence: aleksandra.glowacka@up.lublin.pl; Tel.: +48-81-445-66-23
}

\section{check for}

updates

Citation: Stepaniuk, M.; Głowacka, A. Yield of Winter Oilseed Rape (Brassica napus L. var. napus) in a Short-Term Monoculture and the Macronutrient Accumulation in Relation to the Dose and Method of Sulphur Application. Agronomy 2022, 12, 68. https://doi.org/10.3390/ agronomy12010068

Academic Editors: Christos Noulas, Shahram Torabian and Ruijun Qin

Received: 1 December 2021

Accepted: 24 December 2021

Published: 28 December 2021

Publisher's Note: MDPI stays neutral with regard to jurisdictional claims in published maps and institutional affiliations.

Copyright: (C) 2021 by the authors. Licensee MDPI, Basel, Switzerland. This article is an open access article distributed under the terms and conditions of the Creative Commons Attribution (CC BY) license (https:// creativecommons.org/licenses/by/ $4.0 /)$.

\begin{abstract}
The objective of this study was to assess the yield efficiency of sulphur-enhanced fertilisers, depending on the dose and application method, in a short-lived (three-year) monoculture of winter oilseed rape under the climate and soil conditions of south-eastern Poland. The experiment was carried out between 2010 and 2013 on winter oilseed rape (Brassica napus L. var. napus) of the Orlando variety, fertilised with different sulphur doses- $-2,20,40$ or $60 \mathrm{~kg} \mathrm{~S} \mathrm{ha}^{-1}$ applied in different method-soil application sowing, foliar application in the spring, and soil application sowing + foliar application in the spring (combined application). Following the harvest, seed and straw yields and the content of macroelements ( $, \mathrm{S}, \mathrm{P}, \mathrm{K}, \mathrm{Ca}$ and $\mathrm{Mg}$ ) in the seed and straw samples were determined. The harvest indices were also established for each of these elements. The impact of sulphur on winter oilseed rape yield depended significantly on both the dose and the application method. Even at the lowest dose $\left(20 \mathrm{~kg} \cdot \mathrm{ha}^{-1}\right)$, sulphur materially increased seed yield, regardless of the application method. With autumn soil application and foliar application, differences between the lowest dose and the higher doses (40 and $60 \mathrm{~kg} \cdot \mathrm{ha}^{-1}$ ) were not significant. However, with combined application, the highest dose $\left(60 \mathrm{~kg} \cdot \mathrm{ha}^{-1}\right)$ significantly increased yield compared to the lower doses. In general, all the fertilisation approaches significantly increased the N, P, K, Ca and Mg contents compared to the control sample, but the differences between them were not substantial. Each of the sulphur application approaches decreased the harvest index for sulphur. The foliar application of each of the doses decreased the harvest indices for N, P, K and Ca. The soil application of $20 \mathrm{~kg} \cdot \mathrm{ha}^{-1}$, and the mixed application of 40 and $60 \mathrm{~kg} \cdot \mathrm{ha}^{-1}$, all increased the harvest indices for $\mathrm{P}, \mathrm{K}$ and Ca.
\end{abstract}

Keywords: oilseed rape; short-lived monoculture; sulphur; yield; seeds; straw; macroelements; harvest index

\section{Introduction}

In terms of cultivation area and production volume, oilseed rape is the second largest oilseed crop in the world, after soybean. Like other species of the family Brassicaceae, oilseed rape has a high demand for sulphur-twice as high as legumes and four times as high as cereals, grasses, maize, or potatoes [1-3]. This is because sulphur performs a number of important physiological functions and is essential for the normal growth and development of these plants [4]. The first information about sulphur deficiencies on oilseed rape plantations appeared in the late 1990s, and since that time, sulphur fertilisation of crop plants, particularly oilseed rape and other species of the family Brassicaceae, has been the subject of numerous studies [5-8]. Sulphur deficiency decreases yield, limits nitrogen uptake, and reduces the content of sulphur-rich metabolites responsible for plants' resistance to biotic and abiotic stress [9]. Many recent experiments have confirmed the beneficial effect of sulphur not only on the yield of crops, but on their quality as well. However, the effect of sulphur application on yield depends on a number of factors, 
including the amount applied and time of application, the form of sulphur used, the sulphur content in the soil (which largely determines its availability for plants), and climate conditions [10-18].

Fertilisation of crop fields with sulphur can raise its content in soil and increase the accumulation of certain minerals in plants due to the acidifying effect of sulphur on soil. Excessive content of these elements can be harmful both for the plant itself and for consumers. According to Podleśna [19], sulphur used in fertilisers can upset the balance in the rhizosphere and thereby have a strong effect on the uptake of other nutrients. Many other authors point out that fertilisation with sulphur can modify $\mathrm{pH}$ and the microbial activity of soil, thus increasing the concentrations of some elements in the plant tissue, particularly heavy metals [20-22]. Furthermore, some elements increase the growth rate of plant mass, causing a decrease or increase in the concentrations of other elements, and thus in their total accumulation. This is important because the mineral concentrations in plant tissues are associated not only with plant growth and development dynamics, but also with resistance to disease, freezing, or other stress conditions during the growing period, and therefore with crop quality [19]. According to Jankowski et al. [7,22], sulphur fertilisation of oilseed rape, by modifying the content of minerals in the plants, can significantly influence the fertiliser value of crop residues (roots or straw) and the quality of seeds used for oil extraction.

The literature contains information confirming the effect of sulphur application on the content and accumulation of minerals in crop plants. Podleśna [19] found that sulphur application at a rate of $80-100 \mathrm{~kg} \mathrm{~S} \cdot \mathrm{ha}^{-1}$ increased the concentrations of sulphur and nitrogen in the seeds and straw of oilseed rape and of calcium only in the straw. Changes in the content of other macroelements, i.e., phosphorus, potassium and magnesium, were not significant. The simultaneous increase in the dry matter of rape significantly increased the total accumulation of the elements which tested relative to the control plants. Jankowski et al. [7] reported that sulphur applied at a rate of $60 \mathrm{~kg} \mathrm{~S} \mathrm{ha}^{-1}$ (in the form of ammonium sulphate) increased the content of potassium, calcium, magnesium and sulphur in winter rapeseed cakes and in the straw (except for $\mathrm{Mg}$ ). The nitrogen content decreased in both the seed cakes and straw, while phosphorus remained unchanged. Lošák et al. [23] showed that fertilisation with sulphur had no effect on nitrogen, phosphorus, or potassium concentrations, but significantly increased the content of sulphur and calcium. Similarly, McGrath and Zhao [24] found that sulphur had no significant effect on the nitrogen concentration in oilseed rape stems.

In the last two decades, sulphur fertilisation of crops, particularly oilseed rape and other species of the family Brassicaceae, has been the subject of many studies. However, there have been no field studies on sulphur fertilisation of winter oilseed rape grown in monoculture. Due to the significant increase in winter oilseed rape production, it may be grown on the same field more often. The aim of the study was to assess the effect of fertilisation with sulphur $\left(\mathrm{Na}_{2} \mathrm{SO}_{4}\right)$ on yield, depending on the rate and means of application, in a short-term (three-year) monoculture of the Orlando cultivar of winter oilseed rape in the climate and soil conditions of south-eastern Poland. A second objective was to assess the effect of sulphur application on the content of macroelements in the seeds and straw of rapeseed.

\section{Materials and Methods}

\subsection{Site Description and Experimental Design}

A field experiment was carried out in the years 2010-2013 in the village of Kolonia Franusin ( $50^{\circ} 32^{\prime} 40^{\prime \prime} \mathrm{N} 23^{\circ} 51^{\prime} 30^{\prime \prime}$ E) in Telatyn Commune, Tomaszów County, Lubelskie Voivodeship. The experiment was set up on mineral brown soil of the group Cambisols (WRB. IUSS Working Group 2014) rich in organic carbon, with the granulometric composition of clayey silt [25], and a slightly acidic reaction $\left(\mathrm{pH}_{\mathrm{KCl}} 6.2\right)$. The most important physicochemical properties of the soil are presented in Table 1 . The soil $\mathrm{pH}$ was determined by potentiometric method (in the suspensions of soil and $1 \mathrm{M}$ solution of $\mathrm{KCl} 1$ 1:2.5) accord- 
ing to PN-ISO 10390:1997 [26]; Corg. was determined by the Tiurin method (the oxidation of organic carbon to $\mathrm{CO}_{2}$ using potassium dichromate $\mathrm{K}_{2} \mathrm{Cr}_{2} \mathrm{O}_{7}$, in the presence of concentrated sulphuric acid $\mathrm{H}_{2} \mathrm{SO}_{4}$ and the silver sulphate- $\mathrm{Ag}_{2} \mathrm{SO}_{4}$ ), according to $\mathrm{KQ} / \mathrm{PB}-34$ [27]; the content of available $\mathrm{P}$ and $\mathrm{K}$ was determined by the Egner-Riehm method, according to PN-R-04023:1996 [28] and PN-R-04022:1996 [29], after extraction with calcium lactate; the $\mathrm{Mg}$ content was determined by the Schachtschabel method after extracting from the soil with $\mathrm{CaCl}_{2}$ solution, according to PN-R-04020:1996 + Az1:2004 [30]; sulphate sulphur $\left(\mathrm{S}-\mathrm{SO}_{4}\right)$ content was determined by nephelometric method, according to KQ/PB-44 [27]; the granulometric composition was determined by Casagrande's areometric method as modified by Prószyński, according to KQ/PB-33 [27].

Table 1. Selected soil properties (0-30 $\mathrm{cm}$ depth) before setting up the experiment (2010).

\begin{tabular}{ccc}
\hline Parameters & Unit & Value \\
\hline Granulometric composition & & Clayey silt \\
Sand $(2.0-0.05 \mathrm{~mm})$ & & 12.0 \\
Dust $(0.05-0.02 \mathrm{~mm})$ & $\%$ & 39.0 \\
$(0.02-0.002 \mathrm{~mm})$ & & 35.0 \\
Loam $(<0.002 \mathrm{~mm})$ & & 14.0 \\
$\mathrm{pH}_{\mathrm{KCl}}$ & $\mathrm{g} \mathrm{kg}^{-1}$ & 6.2 \\
$\mathrm{C}_{\text {org }}$ & & 18.1 \\
$\mathrm{~N}_{\text {tot. }}$ & & 1.6 \\
$\mathrm{P}$ & Content of available nutrients & 34.9 \\
$\mathrm{~K}$ & & 93.8 \\
$\mathrm{Mg}^{-S \mathrm{~S}_{4}}$ & $\mathrm{mg} \mathrm{kg}^{-1}$ & 64.5 \\
& & 8.23 \\
\hline
\end{tabular}

The subject of the study was the Orlando cultivar of winter oilseed rape fertilised with varied amounts of sulphur, applied in different ways, for a total of 10 sulphur fertilisation treatments. The experiment was set up in a single-factor, completely randomized design in four replicates. The design of the field experiment is presented in Table 2. The phonological stages $(\mathrm{BBCH})$ of winter oilseed rape were encoding according to [31].

Table 2. Applied variants of sulphur fertilisation.

\begin{tabular}{|c|c|c|c|}
\hline \multirow{3}{*}{$\stackrel{\text { (I) }}{\text { Sulphur Dose }}$} & \multicolumn{3}{|c|}{$\begin{array}{c}\text { (II) } \\
\text { Method of Sulphur Application }\end{array}$} \\
\hline & \multirow{2}{*}{$\begin{array}{c}\text { Pd } \\
\text { Soil Application Sowing }\end{array}$} & D & PdD \\
\hline & & Foliar & Mixed $=\frac{1}{2} \mathbf{P d}+\frac{1}{2} \mathbf{D}$ \\
\hline So & \multicolumn{3}{|c|}{ S0 } \\
\hline $\begin{array}{c}\mathrm{S} 1 \\
20 \mathrm{~kg} \mathrm{~S} \mathrm{ha}^{-1}\end{array}$ & S1Pd & $\begin{array}{c}\text { S1D } \\
\text { One-time application-before budding } \\
(\text { BBCH 35) }\end{array}$ & $\begin{array}{c}\text { S1PdD } \\
\text { Foliar application: } \\
\text { I. before budding (BBCH 35)-10 } \mathrm{kg} \mathrm{S} \mathrm{ha}^{-1} \text {. }\end{array}$ \\
\hline $\begin{array}{c}\mathrm{S} 2 \\
40 \mathrm{~kg} \mathrm{~S} \mathrm{ha}^{-1}\end{array}$ & S2Pd & $\begin{array}{l}\text { S2D (1/2 DI + 1/2 DII) } \\
\text { I. before budding (BBCH 35), } \\
\text { II. beginning of flowering (BBCH 57) }\end{array}$ & $\begin{array}{l}\text { S2PdD }\left(\frac{1}{2} \mathrm{Pd}+\frac{1}{2} \mathrm{D}\right) \\
\text { Foliar application: } \\
\text { I. before budding }(\mathrm{BBCH} 35)-20 \mathrm{~kg} \mathrm{~S} \mathrm{ha}^{-1}\end{array}$ \\
\hline $\begin{array}{c}\mathrm{S} 3 \\
60 \mathrm{~kg} \mathrm{~S} \mathrm{ha}^{-1}\end{array}$ & S3Pd & $\begin{array}{l}\text { S3D (1/3 DI + 1/3 DII + 1/3 DIII) } \\
\text { I. before budding (BBCH 35), } \\
\text { II. beginning of flowering (BBCH 57), } \\
\text { III. full flowering (BBCH 65) }\end{array}$ & $\begin{array}{c}\text { S3PdD }\left(\frac{1}{2} \mathrm{Pd}+\frac{1}{2} \mathrm{D}\right) \\
\text { Foliar application: } \\
\text { I. before budding (BBCH 35)-15 } \mathrm{kg} \mathrm{S} \mathrm{ha}^{-1}, \\
\text { II. beginning of flowering (BBCH } 57)-15 \mathrm{~kg} \mathrm{~S} \mathrm{ha}^{-1}\end{array}$ \\
\hline
\end{tabular}

The area of a single plot was $100 \mathrm{~m}^{2}$. Winter oilseed rape was grown in a threeyear monoculture on a field where the previous crop had been ryegrass (Festuca perennis) grown for seed. After harvesting the seeds, the straw of the forecrop was plowed in. The cultivation technology was in accordance with current recommendations. After harvesting the forecrop, a set of post-harvest crops was made with a cultivator (Konskilde Delta, 
depth 6-8 cm), and then, at seven-day intervals, harrowing was performed twice with a heavy harrow. Then, plowing was carried out with a reversible plow to a depth of 22 $\mathrm{cm}$. A pre-sowing cultivator was used to prepare the soil for sowing and to mix fertilisers. Sowing was performed with a pneumatic seed drill. Prior to sowing, mineral fertiliser was applied as follows (in $\mathrm{kg} \cdot \mathrm{ha}^{-1}$ ): $\mathrm{P}_{2} \mathrm{O}_{5}-40 \mathrm{~kg} \cdot \mathrm{ha}^{-1}$ (Super Fos Dar), $\mathrm{K}_{2} \mathrm{O}-60 \mathrm{~kg} \cdot \mathrm{ha}^{-1}$ (potassium salt) and the first rate of nitrogen at $\mathrm{N}-31 \mathrm{~kg} \cdot \mathrm{ha}^{-1}$ (ammonium nitrate). The second nitrogen rate of $96 \mathrm{~kg} \mathrm{ha}^{-1}$ was applied in the spring before the start of growth (BBCH 25), using ammonium nitrate. The third nitrogen rate of $48 \mathrm{~kg} \mathrm{ha}^{-1}$ was applied at the beginning of budding ( $\mathrm{BBCH} 34$ ) also using ammonium nitrate. Sulphur was applied in the form of anhydrous sodium sulphate $\left(\mathrm{Na}_{2} \mathrm{SO}_{4}\right)$. The rates, means, and times $(\mathrm{BBCH}$ stages) of application are shown in Table 2. For foliar application, sodium sulphate was dissolved in water in the amount of $200 \mathrm{dm}^{3} \cdot \mathrm{ha}^{-1}$.

Seeds of the Orlando cultivar of winter oilseed rape $\left(\mathrm{F}_{1}\right.$ hybrid $)$ were sown at a rate of $3.8 \mathrm{~kg} \cdot \mathrm{ha}^{-1}$, for a density of 50 plants per $\mathrm{m}^{2}$. Seeds were sown between 24 and 28 August, depending on the year, so that during overwintering, rapeseed entered the rosette stage with 8 true leaves and a root neck $7 \mathrm{~mm}$ thick. Plant protection against pathogens, weeds and pests was carried out according to the recommendations of the Institute of Plant Protection in Poznań [32]. Rapeseed was harvested with a combine (Deyth Fahr 4554H) during the fully ripe stage $(\mathrm{BBCH} 89)$. Each year of the experiment, the rape straw was plowed in.

\subsection{Meteorological Conditions}

The weather conditions during the experiment are presented in Figures 1 and 2 and in Tables 3 and 4. Data pertaining to precipitation and air temperature were used to calculate Selyaninov's hydrothermal coefficient for the months in which the average daily air temperature exceeded $8{ }^{\circ} \mathrm{C}$, because in this case, reliable results are obtained [33]. The scale developed by Skowera et al. [34] to define ranges of values for the coefficient was adopted. Precipitation totals in the first season of 2010/2011 (August-July) amounted to $791.7 \mathrm{~mm}$, which was $82 \mathrm{~mm}$ higher than the long-term average. Particularly high precipitation in this season was noted in August and September, substantially exceeding the long-term averages for these months, by 80.8 and $39.5 \mathrm{~mm}$, respectively. In the other two seasons, the precipitation totals during the period from August to July were lower than the long-term average (Figure 1). Particularly low precipitation was noted in the second season of the study $(2011 / 2012)$. Precipitation in the autumn growing period (August-November) of 2011 was only 38\% of the long-term average (Table 3). In all three seasons of the experiment, precipitation during winter dormancy was much lower than the long-term average (1996-2013). The average temperature during the spring growing season (April-July) in all years of the study was higher than the long-term average (Figure 2).

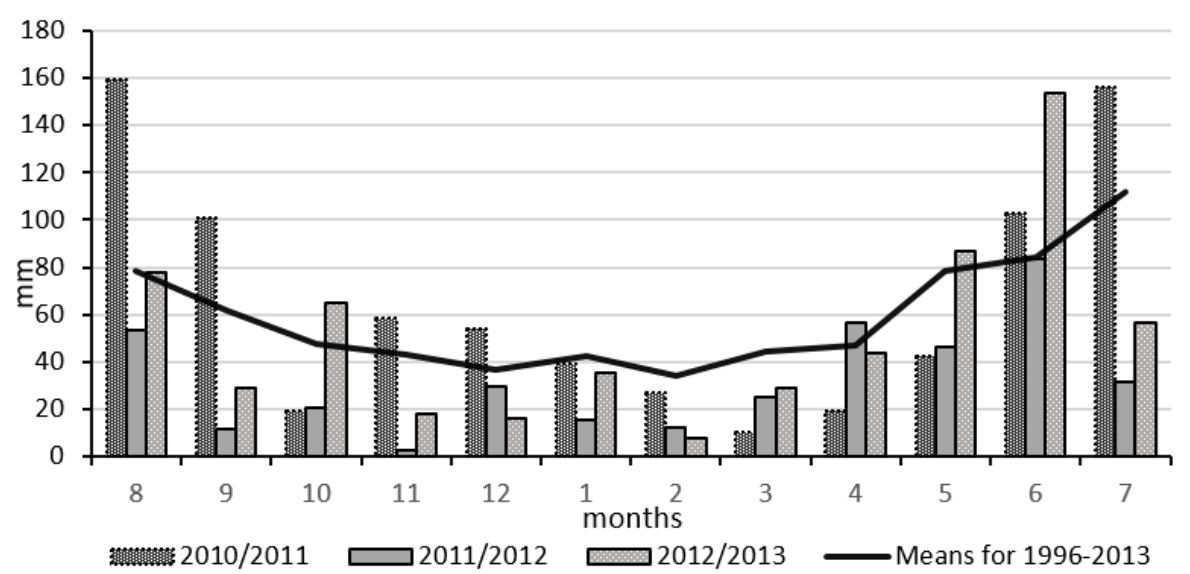

Figure 1. Rainfall in months (according to the COBORU Meteorological Station in Ulhówek) as compared to the long-term means (according to the meteorological station in Tomaszów Lubelski, Institute of Meteorology and Water Management-National Research Institute in Warsaw Meteorological Station). 


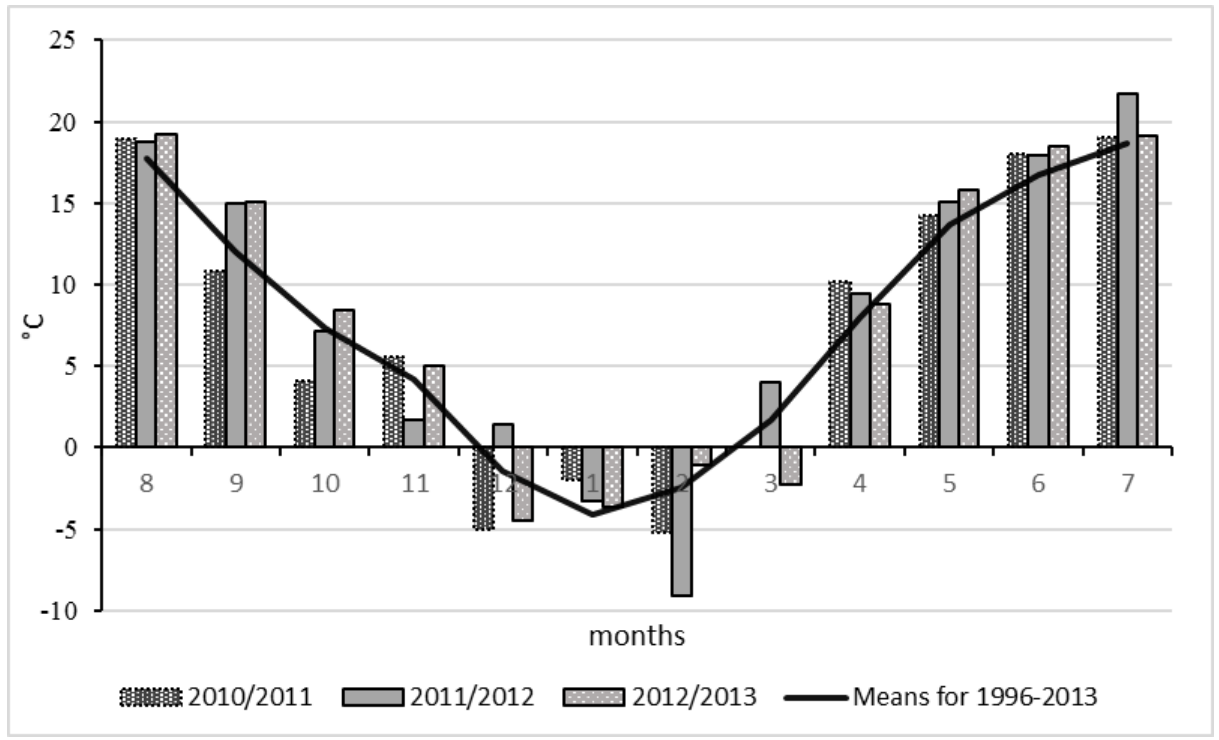

Figure 2. Air temperature in months (according to the COBORU Meteorological Station in Ulhówek) as compared to the long-term means (according to the meteorological station in Tomaszów Lubelski, Institute of Meteorology and Water Management-National Research Institute in Warsaw Meteorological Station).

Table 3. Precipitation and air temperature in months (according to the COBORU Meteorological Station in Ulhówek) compared to the long-term average (1996-2013 according to the meteorological station in Tomaszów Lubelski, Institute of Meteorology and Water Management-National Research Institute in Warsaw).

\begin{tabular}{|c|c|c|c|c|c|c|c|c|}
\hline \multirow{3}{*}{$\begin{array}{l}\text { The } \\
\text { Growing } \\
\text { Season }\end{array}$} & \multicolumn{4}{|c|}{ Temperature $\left({ }^{\circ} \mathrm{C}\right)$} & \multicolumn{4}{|c|}{ Rainfall } \\
\hline & \multicolumn{3}{|c|}{ Deviation from the Long-term Average } & \multirow{2}{*}{$\begin{array}{c}\text { Long-Term } \\
\text { Average }\end{array}$} & \multicolumn{3}{|c|}{$\%$ of the Long-Term Average } & \multirow{2}{*}{$\begin{array}{l}\text { Long-Term } \\
\text { Average } \\
\text { (mm) }\end{array}$} \\
\hline & $2010 / 2011$ & $2011 / 2012$ & $2012 / 2013$ & & $2010 / 2011$ & 2011/2012 & $2012 / 2013$ & \\
\hline $\begin{array}{c}\text { Autumn } \\
\text { August- } \\
\text { November }\end{array}$ & -0.4 & +0.4 & +1.7 & 10.3 & 146.7 & 38.2 & 82.2 & 230.8 \\
\hline $\begin{array}{l}\text { Winter } \\
\text { dormancy } \\
\text { December- } \\
\text { March }\end{array}$ & -1.5 & -0.2 & -1.3 & -1.6 & 83.6 & 52.7 & 55.8 & 157.4 \\
\hline $\begin{array}{c}\text { Spring } \\
\text { April-July }\end{array}$ & +1.1 & +1.7 & +1.3 & 14.3 & 100 & 67.9 & 106.3 & 321.5 \\
\hline
\end{tabular}

Table 4. Selyaninov's hydrothermal coefficient (K) in 2010-2013 compared to the long-term average (1996-2013).

\begin{tabular}{|c|c|c|c|c|c|c|}
\hline \multirow{2}{*}{ Year } & \multicolumn{6}{|c|}{ Months } \\
\hline & April & May & June & July & August & September \\
\hline 2010 & - & - & - & - & 2.72 & 3.12 \\
\hline 2011 & 0.64 & 0.92 & 1.90 & 2.66 & 0.91 & 0.25 \\
\hline 2012 & 2.01 & 0.99 & 1.55 & 0.47 & 1.30 & 0.64 \\
\hline 2013 & 1.77 & 1.78 & 2.78 & 0.96 & - & - \\
\hline $\begin{array}{c}\text { The } \\
\text { long-term } \\
\text { average for } \\
\text { 1996-2013 }\end{array}$ & 1.97 & 1.84 & 1.68 & 1.93 & 1.43 & 1.71 \\
\hline
\end{tabular}


Based on Selyaninov's hydrothermal coefficient, the periods from April to September 1995-2013 can be described as optimal or fairly wet (Table 4). In contrast, during the experiment, there were dry or very dry periods (April, May, August and September 2011 and July and September 2012) as well as very wet periods (August and September 2010 and June 2013).

\subsection{Measurements}

Each year after harvest, the seed yield from each plot was determined and, following correction to $13 \%$ moisture, calculated per ha. The straw yield from each plot was determined as well.

After harvest, samples of plant material (seeds and straw) were taken from each plot for chemical analysis. The following were determined in the seed and straw samples: total sulphur by nephelometry (KQ/PB-31 version 04 of 02/07/12) - the method consists in the oxidation of organic and inorganic sulphur to $\mathrm{SO}_{4}$ in an electric muffle furnace at $550{ }^{\circ} \mathrm{C}$ in the presence of sodium bicarbonate and oxygen from the air, followed by nephelometric determination in the form of $\mathrm{BaSO}_{4}$; total $\mathrm{N}$ by the Kjeldahl method (KQ/PB-70 version 02 of $01 / 12 / 10$ ) - the method consists in converting the amide form of nitrogen into ammonia by mineralisation with concentrated sulphuric acid, then distillation of ammonia and absorption in a sulphuric acid solution and titration of the excess acid with a standard sodium hydroxide solution; phosphorus by the vanadomolybdate method (KQ/PB-24 version 03 of $01 / 12 / 10$ ) - the method consists in measuring by spectrophotometry the intensity of the yellow color of the phosphor-vanadium-molybdic acid complex, which is formed by orthophosphate and vanadium ions in the presence of molybdate in an acidic environment, the measurement is made at a wavelength of $470 \mathrm{~nm}$; potassium and calcium (KQ/PB-25 version 03 of 01/12/10) by flame photometry-after mineralisation in concentrated nitric acid, the nebulized solution is mixed with the flammable gas, and next, the mixture burns at the exit of the burner. The burner flame, in which the elements are excited, is a radiation source located in an optical system containing appropriate filters and a detector. The K-77J filter is used to determine the potassium content, and the Ca-63J filter for the determination of calcium; magnesium (KQ/PB-26 version 03 of 01/12/10) by atomic absorption spectrometry - the method is based on measuring the absorption of radiation emitted by magnesium atoms released when the solution is sprayed into an acetylene-air flame.

The analyses of the content of N, S, P, K, Ca and Mg were performed in the accredited laboratory of the Regional Chemical and Agricultural Testing Station in Lublin according to the procedures developed on the basis of the methodology of Institute of Soil Science and Plant Cultivation-State Research Institute in Puławy [27,35].

Then the harvest index for accumulation of $\mathrm{N}, \mathrm{S}, \mathrm{P}, \mathrm{K}, \mathrm{Ca}$ and $\mathrm{Mg}$ was calculated, i.e., the amount of the element accumulated in the seeds as a percentage of its total amount accumulated in the plant.

\subsection{Statistical Analysis}

Statistical analysis of the results was performed using Excel 2016 and STATISTICA 13 PL software (Tulsa, USA). Two-way analysis of variance (ANOVA) was performed, and Tukey's test was used to verify the significance between means at $\alpha=0.05$.

\section{Results and Discussion}

\subsection{Yield of Seeds and Straw}

Oilseed rape yield depends on the genetically determined yield potential of a given cultivar and its response to environmental and agrotechnical conditions. Weather conditions were varied in the years of the study (2010-2013), and weather was found to significantly influence both the seed yield and the straw yield of rapeseed. Extreme moisture conditions were noted in the 2011/2012 season. In September 2011, only $2.5 \mathrm{~mm}$ of rain fell, and Selyaninov's hydrothermal coefficient $(\mathrm{k}=0.25)$ confirms that this was a dry period. The 
precipitation total for the period from August 2011 to July 2012 was only 55\% of the longterm average for this period. Moreover, in that season, there were very low temperatures in February $-6.6^{\circ} \mathrm{C}$ lower than the long-term average. The unfavourable weather conditions clearly affected the seed and straw yield of rapeseed (Table 5). Many previous studies confirm that weather conditions strongly affect seed yields of rape [36-39]. Wielebski [40] obtained the highest rapeseed yield in the season when moderate temperatures in the spring were accompanied by a beneficial rainfall distribution. These favourable moisture and temperature parameters ensured good pod formation and seed formation in the pod. In the present study, the rainfall and temperature distribution in the spring growing period was favourable in 2011 and in 2013, when the highest yields were obtained. The autumn growing period in 2010 (August-November) was distinguished by heavy rainfall, amounting to $147 \%$ of the long-term average, and Selyaninov's hydrothermal coefficient was 2.27 (very wet) for August and 3.12 (extremely wet) for September. The following April (2011) was a very dry period $(k=0.64)$, and May was dry $(k=0.92)$ [27]. This may have been the cause of the poorer yields obtained in 2011 in comparison to 2013.

Table 5. The influence of variants of sulphur fertilisation on the yield of seeds and straw of winter rape.

\begin{tabular}{|c|c|c|c|c|c|c|}
\hline \multirow{2}{*}{$\begin{array}{c}\text { Variants of } \\
\text { Sulphur } \\
\text { Fertilisation } \\
\end{array}$} & \multicolumn{3}{|c|}{ Seeds Yield (dt ha $\left.{ }^{-1}\right)$} & \multicolumn{3}{|c|}{ Straw Yield (dt ha $\left.{ }^{-1}\right)$} \\
\hline & 2011 & 2012 & 2013 & 2011 & 2012 & 2013 \\
\hline so & $39.16^{\text {de }} \pm 0.75$ & $30.60^{\mathrm{a}} \pm 0.47$ & $38.36^{\mathrm{d}} \pm 1.30$ & $83.10^{\mathrm{cd}} \pm 2.91$ & $78.40^{b c} \pm 1.21$ & $94.00^{\mathrm{fgh}} \pm 3.18$ \\
\hline S1Pd & 39.79 def \pm 0.42 & $32.88^{a b} \pm 0.40$ & $41.55^{\mathrm{fg}} \pm 1.20$ & 94.78 ghi \pm 0.90 & $74.20^{\mathrm{ab}} \pm 0.89$ & $107.40^{\text {no }} \pm 3.10$ \\
\hline $\mathrm{S} 2 \mathrm{Pd}$ & $40.95^{\text {efg }} \pm 0.73$ & $33.12^{b c} \pm 0.54$ & $41.33^{\text {efg }} \pm 0.77$ & $106.5^{\mathrm{llm}} \pm 2.54$ & $69.50^{\mathrm{a}} \pm 1.13$ & $115.60 \mathrm{pq} \pm 2.16$ \\
\hline S3Pd & $41.84^{\mathrm{fgh}} \pm 0.75$ & $33.72^{c} \pm 0.71$ & $41.54 \mathrm{fg} \pm 0.95$ & $90.2^{\text {efg }} \pm 1.95$ & 94.70 ghi \pm 1.99 & $101.70^{\mathrm{j}-\mathrm{n}} \pm 2.34$ \\
\hline S1D & $41.76^{\mathrm{fg}} \pm 0.74$ & $30.96^{a b c} \pm 0.99$ & $44.19^{\text {hij }} \pm 0.79$ & $117.8^{\mathrm{n}} \pm 2.07$ & $100.70^{\mathrm{i}-1} \pm 3.22$ & $108.60^{\circ} \pm 1.94$ \\
\hline S2D & $40.76^{\text {efg }} \pm 0.80$ & $32.76^{\mathrm{abc}} \pm 0.71$ & $42.74^{\mathrm{g}-\mathrm{j}} \pm 0.88$ & $104.6 \mathrm{k}^{\mathrm{llm}} \pm 2.06$ & $102.10^{\mathrm{klt}} \pm 2.21$ & $100.10^{\mathrm{h}-1} \pm 2.06$ \\
\hline S3D & $42.28^{\mathrm{g}-\mathrm{j}} \pm 0.75$ & $32.64^{\mathrm{abc}} \pm 1.03$ & $44.42^{\mathrm{j}} \pm 0.53$ & $100.2^{\mathrm{h}-1} \pm 1.78$ & $96.00^{g-j} \pm 3.02$ & $101.80^{\mathrm{j}-\mathrm{n}} \pm 1.21$ \\
\hline S1PdD & $40.76^{\text {efg }} \pm 0.56$ & $32.52^{a b c} \pm 0.71$ & 41.29 efg \pm 0.86 & $87.9^{\text {def }} \pm 1.43$ & $104.40^{1-o} \pm 2.28$ & $93.40^{\mathrm{fg}} \pm 1.94$ \\
\hline S2PdD & $41.64^{\mathrm{fg}} \pm 0.92$ & $32.28^{a b c} \pm 0.86$ & $41.20^{\text {efg }} \pm 0.59$ & $106.3^{\mathrm{k}-\mathrm{m}} \pm 1.98$ & $77.70^{b c} \pm 2.06$ & $109.70^{o p} \pm 1.58$ \\
\hline S3PdD & $42.10^{\mathrm{f}-\mathrm{i}} \pm 0.80$ & $33.60^{c} \pm 0.59$ & $44.50^{\mathrm{j}} \pm 0.89$ & $86.80^{\text {de }} \pm 1.66$ & $71.30^{\mathrm{a}} \pm 1.25$ & $109.40^{\mathrm{op}} \pm 2.20$ \\
\hline Mean & $41.10^{\mathrm{B}} \pm 1.21$ & $32.51^{\mathrm{A}} \pm 1.21$ & $42.11^{C} \pm 1.97$ & $97.91^{\mathrm{B}} \pm 10.69$ & $86.88^{\mathrm{A}} \pm 13.34$ & $104.17^{C} \pm 7.10$ \\
\hline
\end{tabular}

For three seasons, oilseed rape was grown on the same site. The highest yield was obtained in the third year, which indicates that cultivation of winter oilseed rape in a short-term monoculture did not significantly affect yield (Table 5). According to many authors, the yield of oilseed rape decreases when it is grown for a second consecutive season on the same site [41]. An insufficient interval between oilseed rape crops on the same site increases the occurrence of pathogens, pests, and weeds, including pathogenic fungi, which can pose a threat to yield and to crop quality [37,42]. Hegewald et al. [43] also draw attention to the importance of crop rotation in maintaining seed and oil yield of rape. According to many authors, however, oilseed rape occasionally grown for a second consecutive season or in a short monoculture can produce similar yields to crops preceded by cereals [44], or even slightly higher [45]. In a study by Jaskulska et al. [46], the yield of rapeseed grown for a second consecutive season was $4.6 \%$ higher than when preceded by winter wheat and $8.5 \%$, significantly, higher than when preceded by spring barley.

Analysis of our results showed that sulphur application from 20 to $60 \mathrm{~kg} \mathrm{~S} \cdot \mathrm{ha}^{-1}$ significantly increased the seed and straw yield of rape, on average by $8.02 \%$ and $14.2 \%$ (Figure 3a,b). Many studies in various parts of the world have confirmed the positive effect of sulphur application on oilseed rape yield in conditions of sulphur deficiency in the soil $[13-15,17,19,47,48]$. According to many authors $[2,8,23,24]$, the effect of sulphur on yield mainly results from its strong effect on nitrogen metabolism. Sulphur plays an important role in nitrogen metabolism, increasing the rate at which nitrogen taken up by 
the plant is transformed into protein. Nitrogen is the nutrient with the greatest effect on yield, and therefore by influencing nitrogen metabolism, sulphur directly affects seed yield.

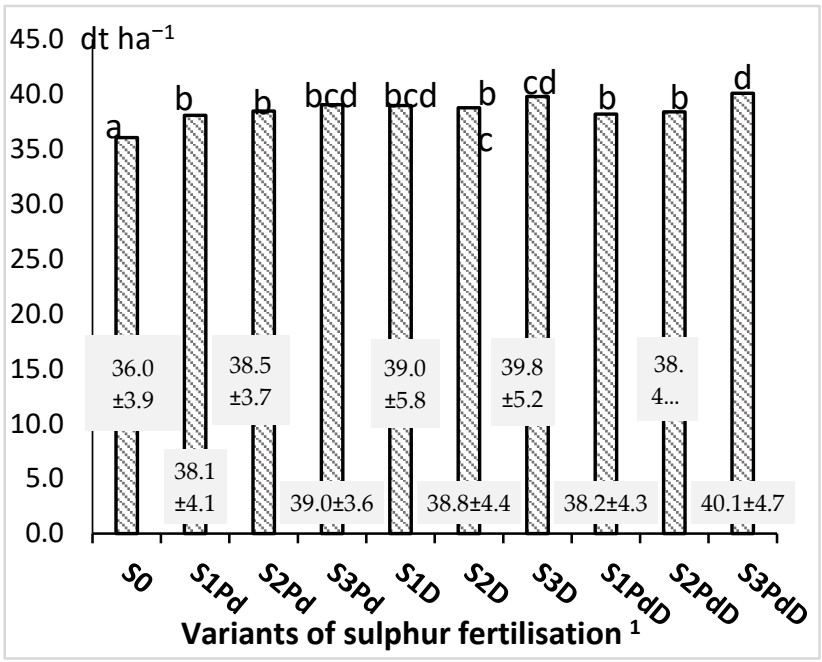

(a)

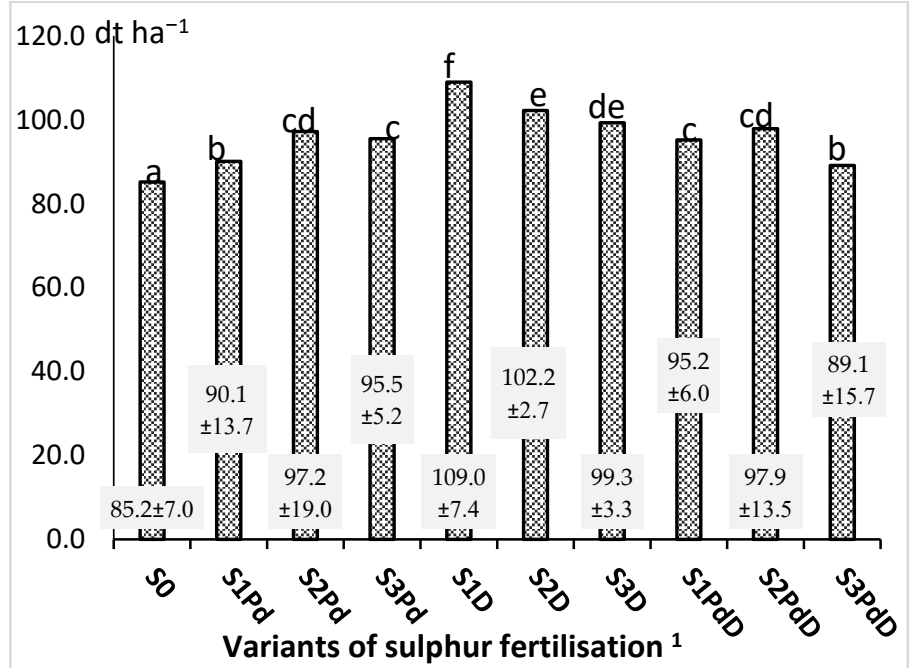

(b)

Figure 3. (a) Average yield of rape seeds for variants of sulphur fertilisation; (b) Average yield of rape straw for variants of sulphur fertilisation. ${ }^{1}$ See Table 2; Means followed by the same letter are not statistically different at the $\alpha=0.05$ level. \pm -standard deviation.

However, the effect of sulphur on yield is not always favourable. There is no question that the positive effect of sulphur on yield is particularly pronounced in conditions of sulphur deficiency. This is confirmed by research by Wielebski and Wójtowicz [49], in which sulphur application in conditions of optimal and very high sulphur did not significantly affect seed yield. Similar findings were reported by Jakubus and Toboła [48] in an experiment conducted on soil with average total sulphur content. The increase in seed yield observed by the authors as a result of sulphur application proved to be statistically non-significant. Many studies have shown no effect or a minor effect on sulphur fertilisation on yield even in conditions of poor soil content of this element $[10,19,50]$.

The effect of sulphur on yield depends on many factors, including the application rate and when it is applied. The present study only partially confirmed this dependency. On average in the experiment, even the lowest level of sulphur application $\left(20 \mathrm{~kg} \mathrm{~S} \cdot \mathrm{ha}^{-1}\right)$, for each means of application, significantly increased seed yield. Increasing the amount applied did not significantly affect seed yield in the case of application of the entire amount of fertiliser to the soil before sowing or to the leaves. Significant differences in the effect of application rates on yield were only observed when sulphur was applied in a mixed manner, i.e., half to the soil before sowing and half to the leaves. In this case, application in the amount of $60 \mathrm{~kg} \mathrm{~S} \cdot \mathrm{ha}^{-1}$ had the most beneficial effect on seed yield (Figure 3a).

Sienkiewicz-Cholewa and Kieloch [16] report that sulphur application before sowing in the amount of $20 \mathrm{~kg} \mathrm{~S} \cdot \mathrm{ha}^{-1}$ had no effect on rapeseed yield. Only higher application rates (40 or $60 \mathrm{~kg} \mathrm{~S} \cdot \mathrm{ha}^{-1}$ ) significantly increased seed yield, by 11-12\% relative to the control (3.5-6.1 dt.ha $\left.{ }^{-1}\right)$. In a study by Wielebski [51], application of sulphur in early spring at levels from 15 to $60 \mathrm{~kg} \mathrm{~S} \cdot \mathrm{ha}^{-1}$ increased seed yield by $4.6 \%$ on average. Application of $15 \mathrm{~kg} \mathrm{~S} \cdot \mathrm{ha}^{-1}$ was sufficient to achieve the highest yield, and higher application of sulphur (30 and $60 \mathrm{~kg} \mathrm{~S} \cdot \mathrm{ha}^{-1}$ ) did not significantly differentiate yield compared to $15 \mathrm{~kg} \mathrm{~S} \cdot \mathrm{ha}^{-1}$. Dash et al. [15], on the other hand, obtained the most beneficial effect on oilseed rape yield by applying $40 \mathrm{~kg} \mathrm{~S} \cdot \mathrm{ha}^{-1}$. In the present study, fertilisation with $60 \mathrm{~kg} \cdot \mathrm{ha}^{-1}$ resulted in the highest yield for every means of application. However, when the entire amount of fertiliser was applied to the soil before sowing or to the leaves, the differences in yield (56$102 \mathrm{~kg} \cdot \mathrm{ha}^{-1}$ ) between this level of sulphur and lower application rates were not significant 
(Figure 3a). In the case of mixed application of $60 \mathrm{~kg}$, the second portion of sulphur for foliar application $\left(15 \mathrm{~kg} \mathrm{~S} \cdot \mathrm{ha}^{-1}\right)$ was applied at the start of the flowering stage $(\mathrm{BBCH}$ 57). According to many authors, oilseed rape has high sulphur requirements, especially from the budding stage to the pod forming stage [52,53]. Availability of sulphur during this period ensures the proper growth and development of rape. Janzen and Bettany [54] also claim that sulphur fertilisers fundamentally affect crop yield. The authors observed particularly favourable effects of fertiliser applied at the budding stage. According to Grant et al. [55], if sulphur deficiencies are observed during the growing season, application of sulphate sulphur during the period from the start of flowering may be beneficial, although yields will generally be lower than if sulphur is available from the start of plant growth.

On average in our experiment, the method of application did not significantly influence the effect of individual levels of sulphur application on yield (Figure 3a). Contrasting results were obtained in a pot experiment by Podleśna [56], in which foliar feeding of rape plants with magnesium sulphate during flower bud formation resulted in a seed yield that was only $73 \%$ of that obtained following soil application of sulphur. Oilseed rape with access to mineral sulphur from the start of the growing period produced a significantly higher seed yield and greater weight of stems, leaves, pods, and roots. The effect obtained from soil application may be explained by the fact that the sulphur compounds contained in the solution applied to the leaves may cause leaf burn, which interferes with photosynthesis and transpiration and negatively affects crop yields [57]. Zhao et al. [58] observed that sulphur was much less effective when applied in autumn than in spring, and that poor utilisation of sulphur was due to losses via leaching. According to Podleśna [56], only limited amounts of sulphur can be applied to the leaves, because it is not easily transported from the leaves to other organs. Booth et al. [59] claim that sulphur uptake efficiency by leaves is only $2 \%$. The rest ends up in the soil, where it is gradually released and taken up by the root system.

The statistical analysis confirmed a significant interaction of the sulphur fertilisation treatments with the years of the study (Table 5). In the case of soil application in the $2010 / 2011$ season, only the highest application rate of $60 \mathrm{~kg} \mathrm{~S} \cdot \mathrm{ha}^{-1}$ was effective, but this means of application was more effective in the 2011/2012 season. Overall, sulphur fertilisation was least effective in 2011/2012. In August and September 2012, precipitation was very heavy, far exceeding the long-term average. According to Podleśna [19], high levels of precipitation are conducive to leaching of sulphates supplied to the soil in autumn. In our study, sulphur was applied in the form of sodium sulphate. $\mathrm{SO}_{4}{ }^{2-}$ ions are highly mobile, and their retention in the upper layers of the soil in these conditions is very low. According to Wielebski [40], in these conditions, the amount of sulphur introduced with fertiliser before sowing significantly decreases, and in spring, when oilseed rape has the greatest need for sulphur, the plants have a smaller pool of it at their disposal.

It should be noted that sulphur application was most effective in the third year of cultivation (Table 5). All sulphur application rates $\left(20,40,60 \mathrm{~kg} \mathrm{~S} \cdot \mathrm{ha}^{-1}\right)$ significantly increased seed yield in comparison to the control. In the case of soil or foliar application, differences between application rates were not significant, but in conditions of mixed application (half soil, half foliar), seed yield following application of $60 \mathrm{~kg} \mathrm{~S} \cdot \mathrm{ha}^{-1}$ was significantly higher in comparison to the other levels.

This can be linked to the effect of sulphur in reducing the occurrence of pathogens. Growing oilseed rape in a monoculture leads to accumulation of pests and pathogens, which can negatively affect the development and yield of the plants [42]. According to Heneklaus et al. [60], the plant's natural resistance to stress caused by diseases and pests decreases in conditions of sulphur deficiency. Increased natural resistance to infections by pathogenic fungi is an effect of greater sulphur availability for plants. The high toxicity of glucosinolate breakdown products for fungal pathogens is significant here. Numerous literature sources confirm that sulphur fertilisation increases the content of glucosinolates in plants $[1,61]$. The beneficial effect of sulphur application in reducing fungal diseases in rape plants has been confirmed by many authors $[62,63]$. 


\subsection{The Macronutrient Content and the Harvest Index of the Accumulation of Elements \\ 3.2.1. Nitrogen and Sulphur}

The content of macroelements in the rape seeds and straw as well as their accumulation were significantly influenced by the years of the study and the sulphur fertilisation treatments, i.e., the amount and time of application. On average for the experiment, the nitrogen content in the seeds was highest following application of $60 \mathrm{~kg} \mathrm{~S} \cdot \mathrm{ha}^{-1}$ entirely to the leaves or in a mixed manner (Figure 4a). The nitrogen content in the straw also increased in conditions of sulphur fertilisation (Figure 4b), but the extent of these changes was highly varied in different years of the study. A significant increase in nitrogen in the straw under the influence of various sulphur application rates and times was observed in the third year of the study (Table S1). Plants well supplied with sulphur take up more nitrogen and utilise it better from fertilisers, especially from large amounts of the nutrient. According to many authors, the use of sulphur in fertiliser influences the nitrogen balance of winter oilseed rape, primarily biosynthesis of protein nitrogen compounds [64-66]. This explains the higher nitrogen content in rape following inclusion of sulphur in fertilisation in other studies as well [17]. The effect of sulphur fertilisation on nitrogen accumulation in plants of the family Brassicaceae, in both the vegetative parts and the seeds, is confirmed by Jan et al. [67] and Barczak et al. [68].

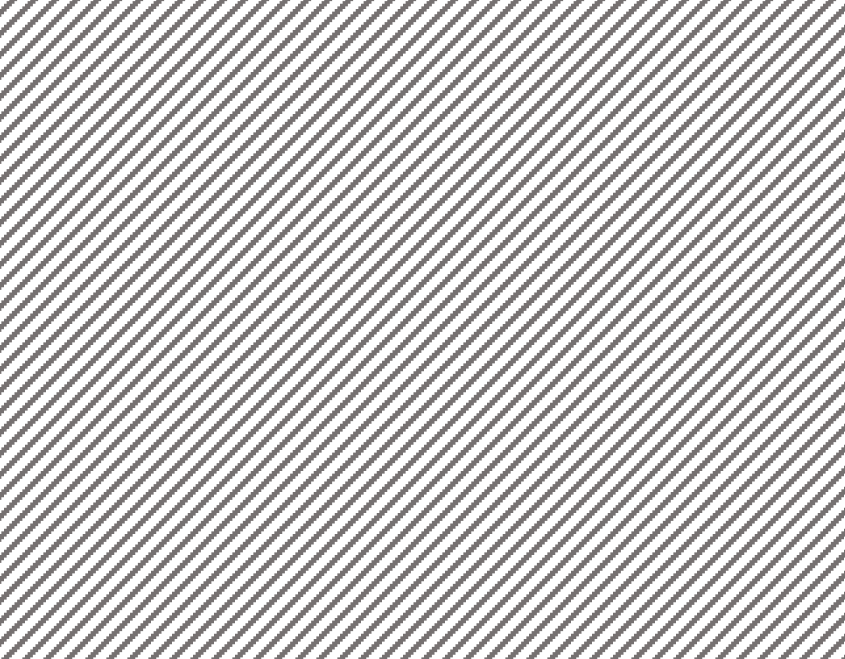

(a)

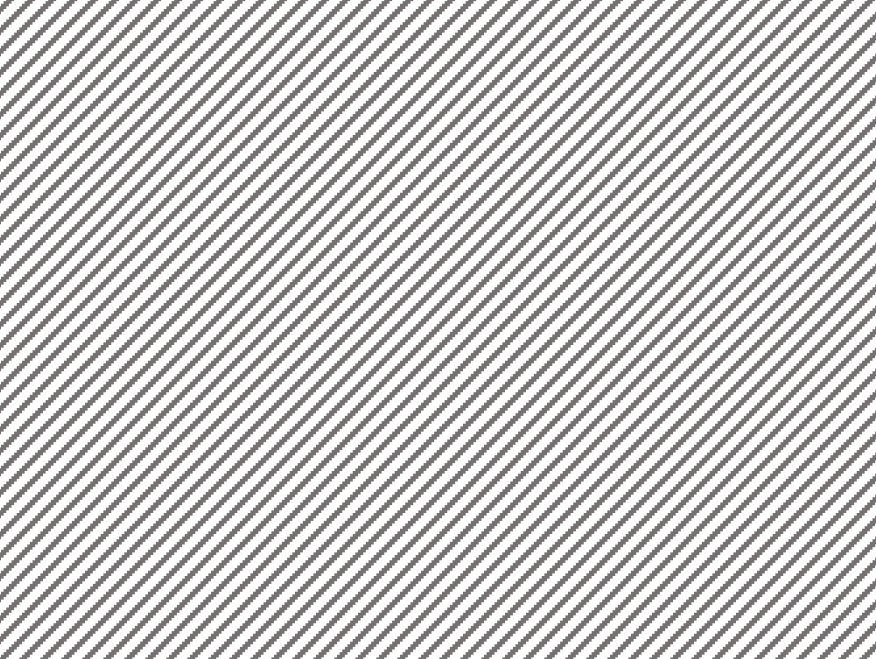

(b)

Figure 4. (a) Nitrogen content in the rape seeds on average for variants of sulphur fertilisation; (b) Nitrogen content in the rape straw on average for variants of sulphur fertilisation. ${ }^{1}$ See Table 2 ; Means followed by the same letter are not statistically different at the $\alpha=0.05$ level. \pm -standard deviation.

Sulphur content in the seeds ranged from 2.31 to $3.14 \mathrm{~g} \cdot \mathrm{kg}^{-1}$ (Table S2) and was much lower than that reported by Jakubus and Toboła [48] and by Podleśna [19], but similar to the content determined by Stepien et al. [69] The sulphur content in plants is determined by a genetic factor, but also by the content of its available forms in the soil, moisture, temperature, and the vicinity of industrial areas [70]. Sulphur fertilisation significantly increased the sulphur content in the rapeseeds, on average by $0.18-0.29 \mathrm{~g}$ relative to the control (Figure 5a). In the case of soil application, the rate of $20 \mathrm{~kg} \mathrm{~S} \cdot \mathrm{ha}^{-1}$ was the most effective. In the case of foliar or mixed application (half soil + half foliar), higher application rates had significantly better effects. The sulphur content in the straw ranged from 1.71 to $4.35 \mathrm{~g} \cdot \mathrm{kg}^{-1}$. Even the lowest level $\left(20 \mathrm{~kg} \mathrm{~S} \cdot \mathrm{ha}^{-1}\right)$ was effective, and as the level of application increased, there was a further increase in the content of sulphur (Figure 5b). 


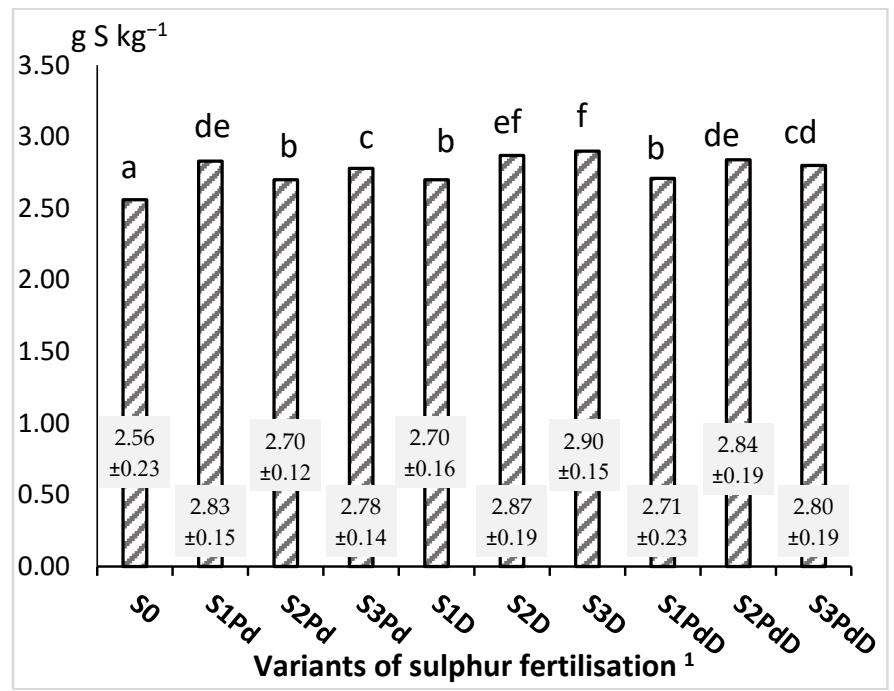

(a)

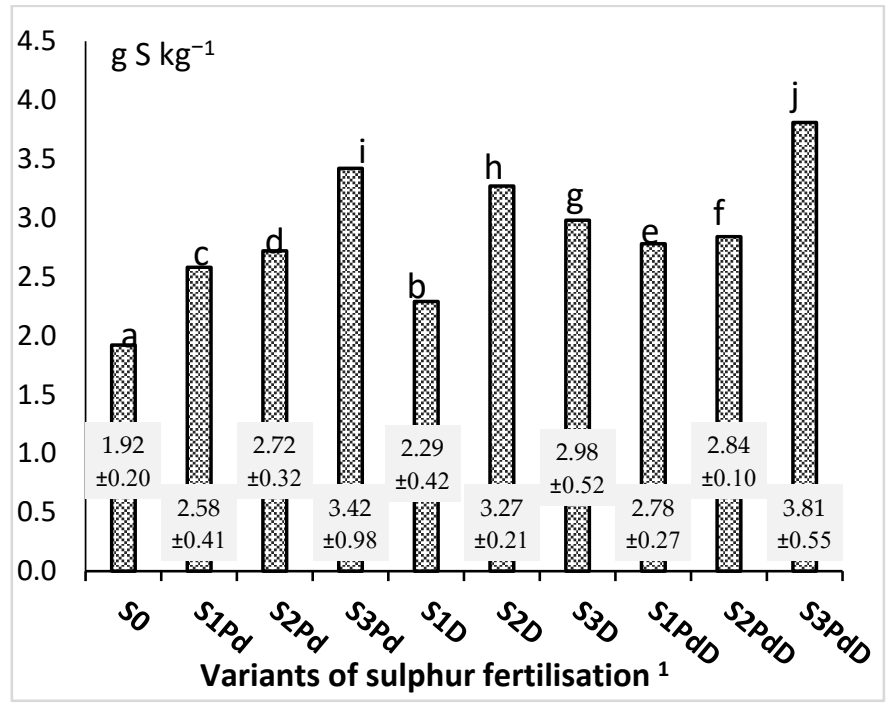

(b)

Figure 5. (a) Sulphur content in the rape seeds on average for variants of sulphur fertilisation; (b) Sulphur content in the rape straw on average for variants of sulphur fertilisation. ${ }^{1}$ See Table 2; Means followed by the same letter are not statistically different at the $\alpha=0.05$ level. \pm -standard deviation.

Podleśna [19] reported that autumn sulphur fertilisation of oilseed rape at $80-100 \mathrm{~kg} \cdot \mathrm{ha}^{-1}$ significantly increased the content of this macroelement in both the seeds and the vegetative parts. Higher sulphur content in oilseed rape following sulphur fertilisation was also noted by McGrath and Zhao [24], Lošák i in. [23] and Podleśna [56]. In contrast, Jakubus and Toboła [48] did not observe an increase in either the content or the uptake of sulphur in seeds following sulphur application; its content in the seeds showed little variation, ranging from 4.2 to 4.7 $\mathrm{g} \cdot \mathrm{kg}^{-1}$, depending on the time and form of fertilisation. A favourable effect was obtained following soil application of ammonium sulphate in autumn and soil and foliar application in spring. Janzen and Bettany [54] report that the time of application of sulphur fertilisers fundamentally affects uptake of sulphur and crop yield. The authors found that fertilisation during the budding stage had a particularly beneficial effect on both parameters. 
The nitrogen harvest index, i.e., the amount of the nitrogen accumulated in the seeds as a percentage of its total accumulation in the plant canopy, was $58.4 \%$ for rape that was not fertilised with sulphur. Sulphur application had varied effects. Foliar application decreased the harvest index. An increase in the index was noted following soil application or mixed application of $60 \mathrm{~kg} \mathrm{~S} \cdot \mathrm{ha}^{-1}$ (Figure 6a, Table S3). In a study by Podleśna [19], more than $70 \%$ of the nitrogen taken up by mature oilseed rape was found in the seeds, and applied sulphur did not affect its distribution among individual organs. According to the author, the high value of the harvest index confirms reports of intensive redistribution of this element from the vegetative organs to the reproductive organs [71]. In another study, Podleśna [55] reported that the amount of nitrogen accumulated in seeds relative to the whole pool of accumulated nitrogen was $66 \%$ and did not differ significantly between crops with soil application vs. foliar spraying of sulphur fertiliser. Grzebisz [71], on the other hand, reported a nitrogen harvest index for winter oilseed rape in a wide range from $45 \%$ to even $70 \%$.

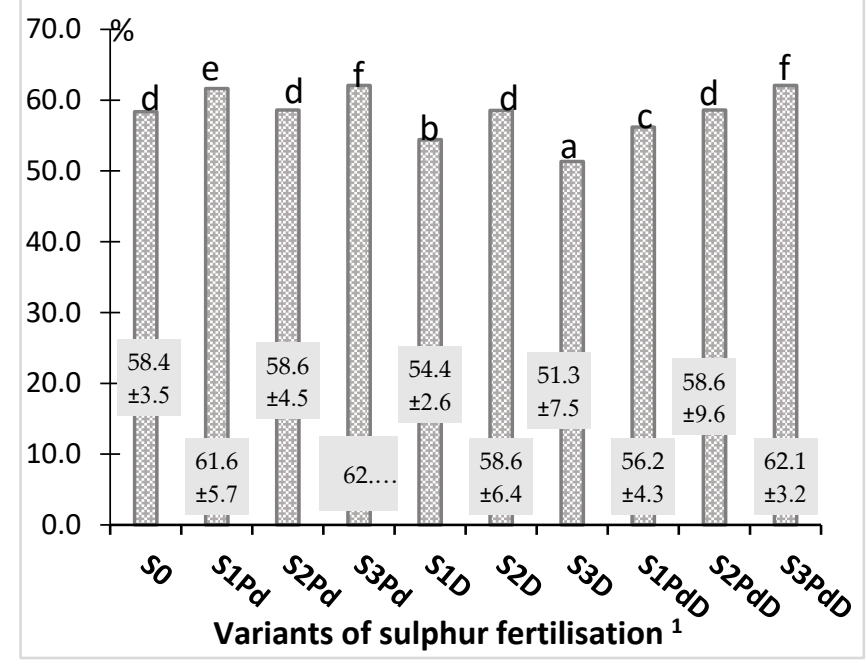

(a)

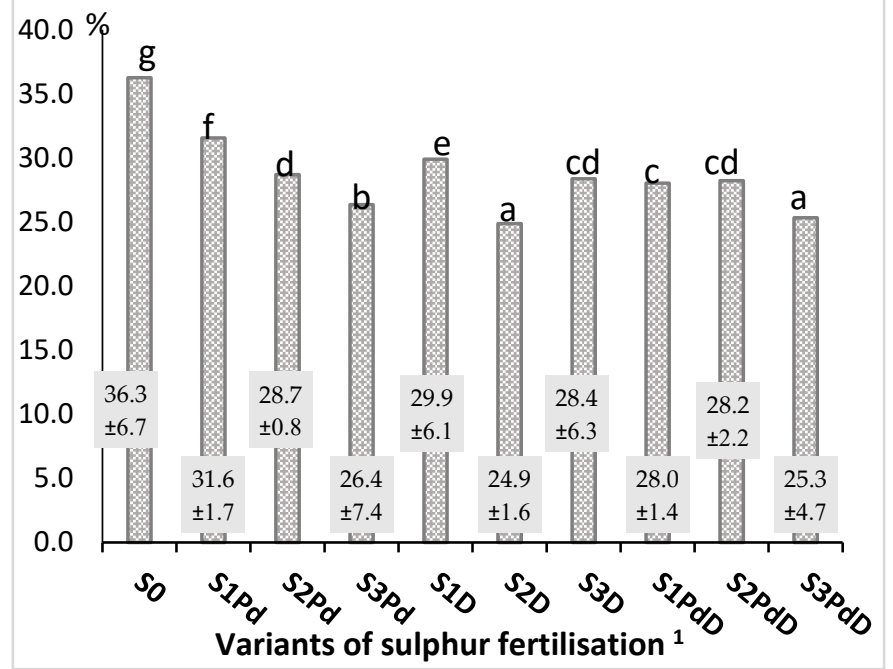

(b)

Figure 6. (a) Nitrogen harvest index on average for variants of sulphur fertilisation; (b) Sulphur harvest index on average for variants of sulphur fertilisation. ${ }^{1}$ See Table 2; Means followed by the same letter are not statistically different at the $\alpha=0.05$ level. \pm -standard deviation.

In the present study, the sulphur harvest index was $36.3 \%$ for the control treatment. It was significantly decreased by sulphur application, especially foliar application of $40 \mathrm{~kg}$ $\mathrm{S} \cdot \mathrm{ha}^{-1}$ and mixed application of $60 \mathrm{~kg} \mathrm{~S} \cdot \mathrm{ha}^{-1}$; for these treatments, it ranged from $24.9 \%$ to 25.3\% (Figure 6b). According to Grzebisz [71], in currently cultivated oilseed rape cultivars, i.e., 00 varieties, sulphur accumulates mainly in the vegetative organs-slightly more in the pods than in the shoots. On the other hand, a study by Podleśna [19] found a sulphur harvest index of about $50 \%$, and it did not depend on sulphur fertilisation.

\subsubsection{Phosphorus and Potassium}

According to Skwierawska et al. [70], the sulphur content in the soil can indirectly affect the rate and level of uptake of other nutrients. This is an important problem in agriculture because it ultimately affects crop quality. The phosphorus content in the seeds in the experiment showed little variation, amounting to $5.87 \mathrm{~g} \mathrm{P} \cdot \mathrm{kg}^{-1}$ in the control and ranging from 6.21 to $6.55 \mathrm{~g} \mathrm{P} \cdot \mathrm{kg}^{-1}$ in the sulphur fertilisation treatments (Table S4). Sulphur fertilisation significantly increased the phosphorus content in the seeds, with a better effect obtained in the case of foliar application. Application of $60 \mathrm{~kg} \mathrm{~S} \cdot \mathrm{ha}^{-1}$ reduced the content of phosphorus in comparison to $40 \mathrm{~kg} \mathrm{~S} \cdot \mathrm{ha}^{-1}$ (Figure 7a). A similar reaction to fertilisation with various amounts of sulphur was observed by Barczak et al. [72] in an experiment on 
lupine. According to the authors, the decrease in the phosphorus content following higher application of sulphur may be due to dilution of phosphorus as a result of the increased yield caused by sulphur fertilisation, and not to an antagonistic effect of phosphate ions (V) and sulphate ions (VI). The phosphorus content in the straw was much lower; it was $1.45 \mathrm{~g}$ $\mathrm{P} \cdot \mathrm{kg}^{-1}$ for the crop that was not fertilised with sulphur (Figure 7b). Skwierawska et al. [73] showed that the phosphorus content in plants was not significantly correlated with the amount and form of sulphur applied. Sulphur application generally increased the amount of phosphorus in the straw, especially foliar application. For this means of application, the phosphorus content increased to $1.96-2.5 \mathrm{~g} \mathrm{P} \cdot \mathrm{kg}^{-1}$, depending on the amount of sulphur applied.

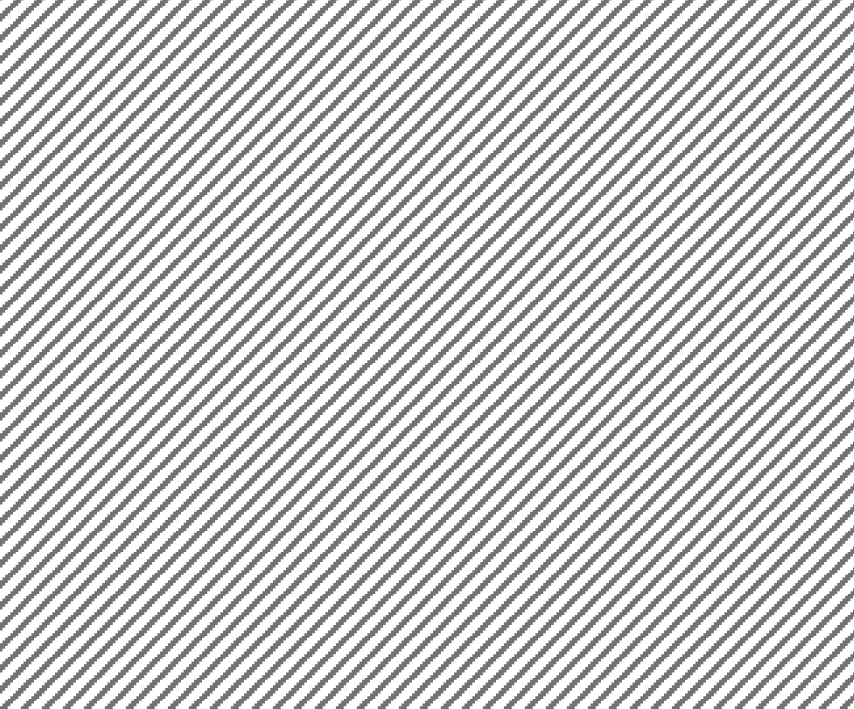

(a)

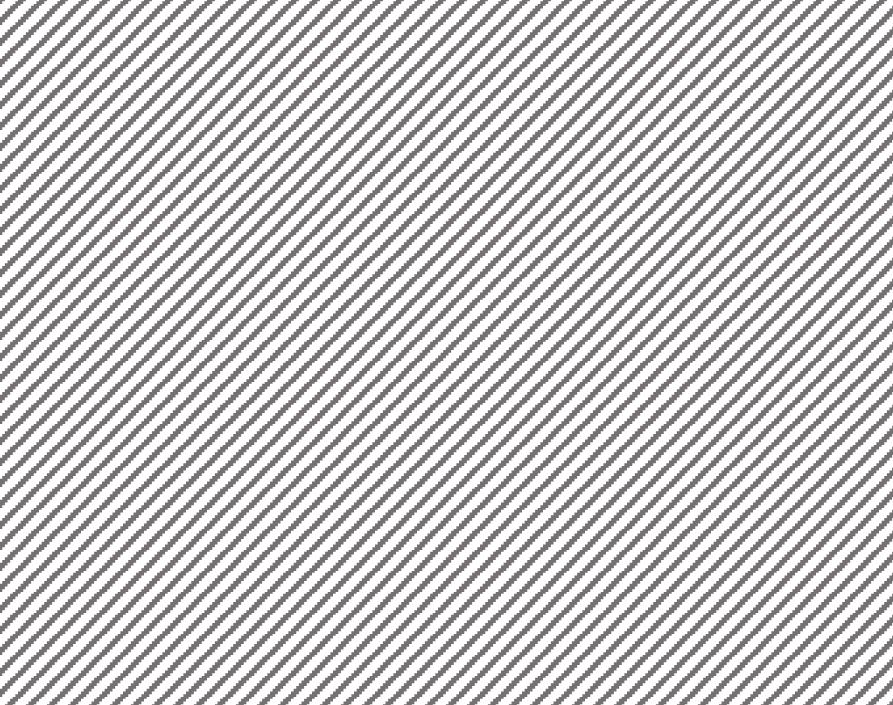

(b)

Figure 7. (a) Phosphorus content in the rape seeds on average for variants of sulphur fertilisation; (b) Phosphorus content in the rape straw on average for variants of sulphur fertilisation. ${ }^{1}$ See Table 2 ; Means followed by the same letter are not statistically different at the $\alpha=0.05$ level. \pm -standard deviation.

Sulphur application increased the content of potassium in the seeds, from $6.28 \mathrm{~g}$ $\mathrm{K} \cdot \mathrm{kg}^{-1}$ in unfertilised plants to $6.45-6.68 \mathrm{~g} \mathrm{~K} \cdot \mathrm{kg}^{-1}$ for various sulphur fertilisation treatments. Changes in potassium content in the straw were more pronounced, and substantial differences were noted between sulphur fertilisation treatments (Figure 8a, Table S5). As in the case of phosphorus, foliar application in each amount was effective (Figure $8 b$ ). In a study by Majmuder et al. [74], sulphur fertilisation (20 and $40 \mathrm{~kg}$ ) significantly increased the potassium content in the seeds, from $5.1 \mathrm{~g} \mathrm{~K} \cdot \mathrm{kg}^{-1}$ to $6.6-7.5 \mathrm{~g} \mathrm{~K} \cdot \mathrm{kg}^{-1}$, and in the straw. Sulphur application also increased the content of available forms of potassium in the soil in the period from flowering to harvest. Szczepanek and Siwik-Ziomek [75] also observed an increase in potassium accumulation in the stems of oilseed rape following the use of sulphur fertiliser. 


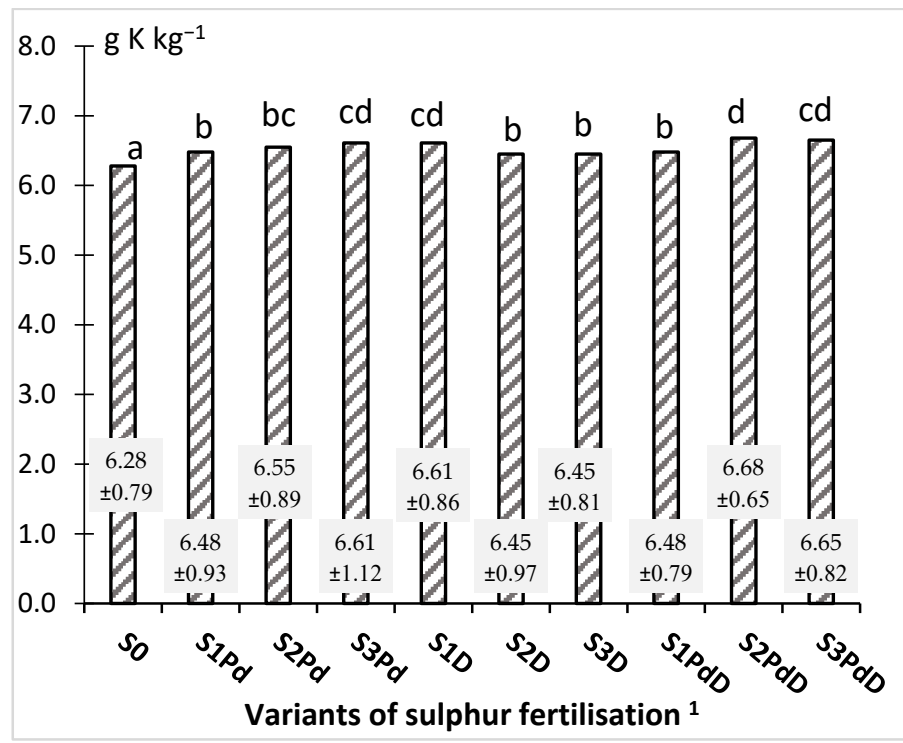

(a)

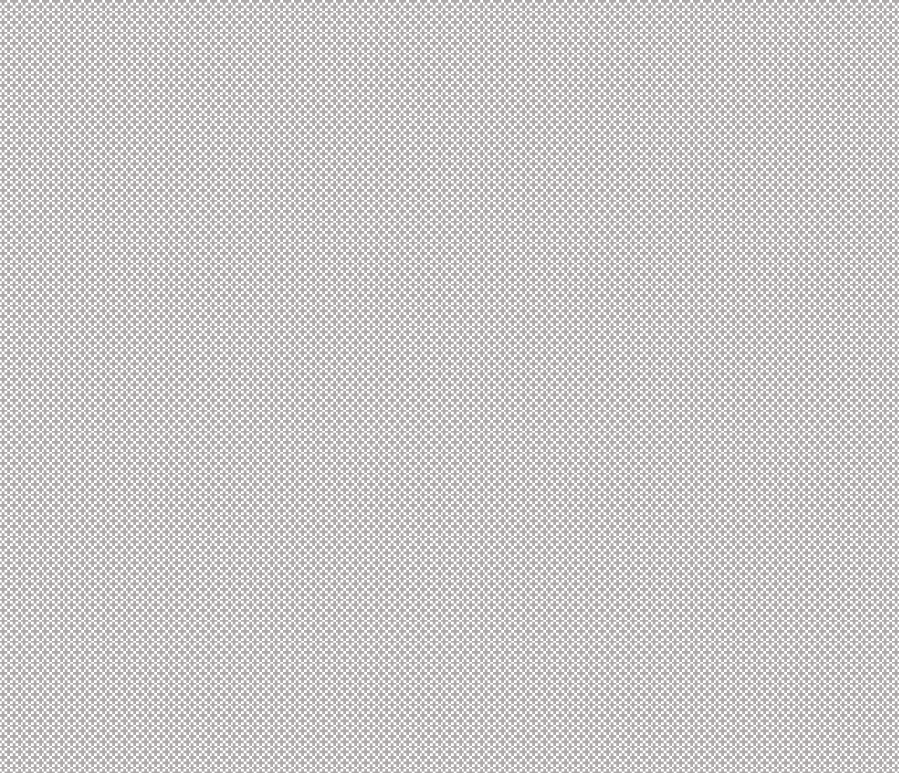

(b)

Figure 8. (a) Potassium content in the rape seeds on average for variants of sulphur fertilisation; (b) Potassium content in the rape straw on average for variants of sulphur fertilisation. ${ }^{1}$ See Table 2 ; Means followed by the same letter are not statistically different at the $\alpha=0.05$ level. \pm -standard deviation.

In the present study, the harvest index for phosphorus accumulation ranged from $42.1 \%$ to $71.3 \%$ (Table S6). Sulphur fertilisation increased the phosphorus harvest index, but only in the case of $20 \mathrm{~kg} \mathrm{~S} \cdot \mathrm{ha}^{-1}$ applied to the soil before sowing and mixed application of 40 and $60 \mathrm{~kg} \mathrm{~S} \cdot \mathrm{ha}^{-1}$. Foliar application decreased the phosphorus harvest index (Figure 9a). According to Grzebisz [71], 45-55\% of total phosphorus taken up by the rape canopy accumulates in the seeds. In an experiment by Podleśna [19], over $80 \%$ of phosphorus taken up was accumulated in the seeds, and sulphur fertilisation had no effect on the phosphorus content in the seeds or in the vegetative parts. 


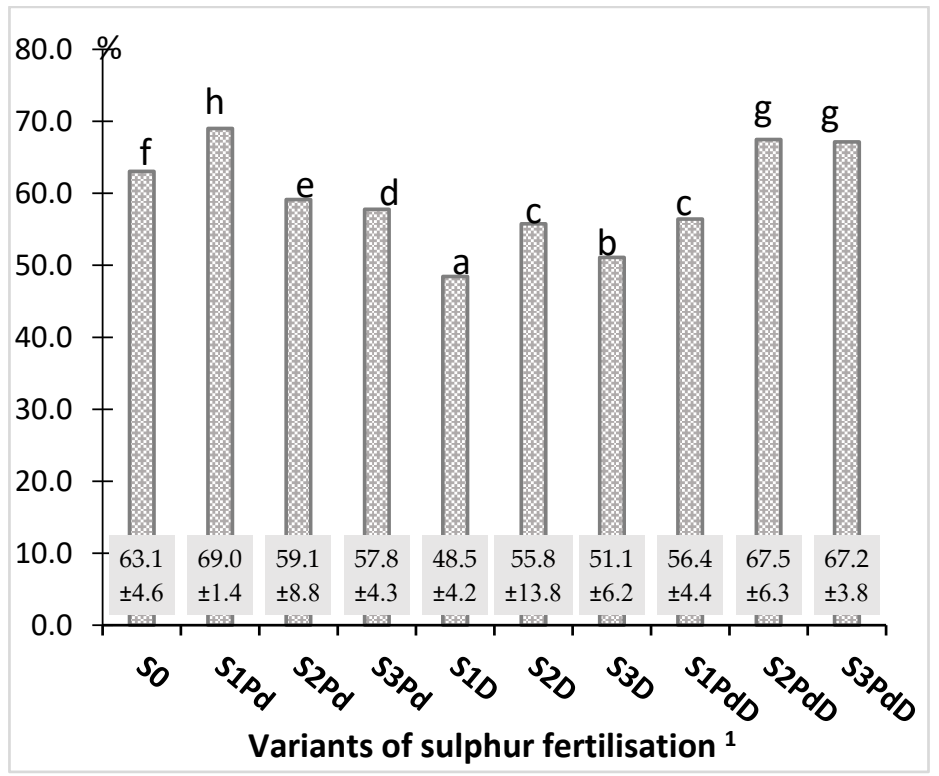

(a)

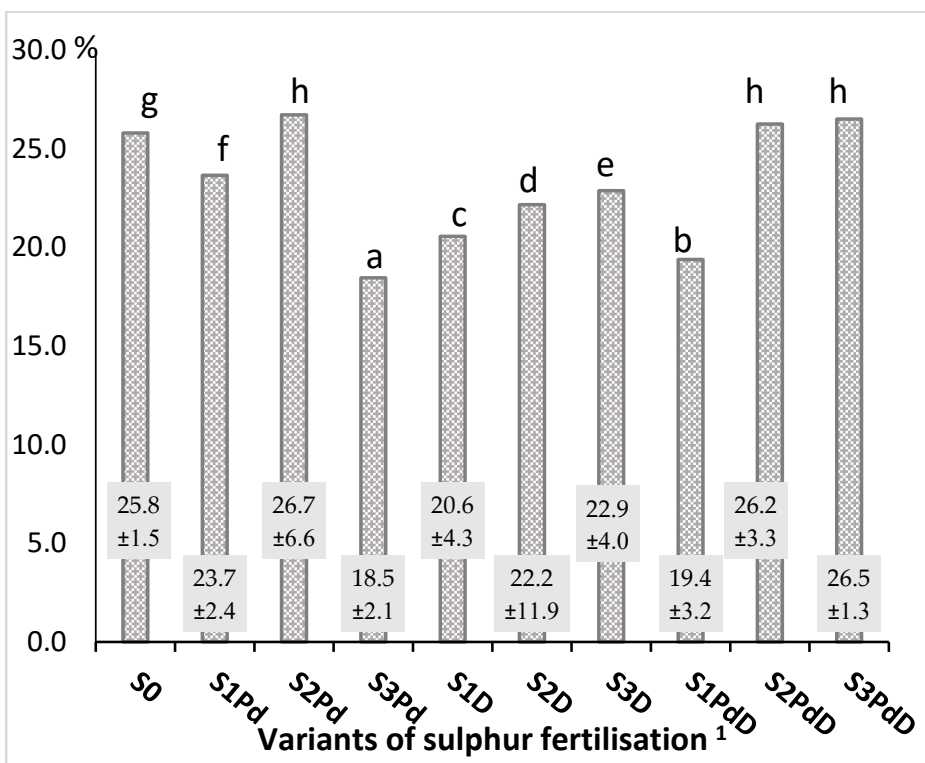

(b)

Figure 9. (a) Phosphorus harvest index on average for variants of sulphur fertilisation; (b) Potassium harvest index on average for variants of sulphur fertilisation. ${ }^{1}$ See Table 2; Means followed by the same letter are not statistically different at the $\alpha=0.05$ level. \pm -standard deviation.

The harvest index for potassium accumulation ranged from $13.26 \%$ to $30.36 \%$. Soil application of sulphur (40 kg S.ha $\left.{ }^{-1}\right)$ and mixed application (40 and $\left.60 \mathrm{~kg} \mathrm{~S} \cdot \mathrm{ha}^{-1}\right)$ significantly increased the potassium harvest index from $25.8 \%$ to $26.5 \%$ (Figure $9 \mathrm{~b}$ ). These results are similar to those obtained by Podleśna [19], who reported that more than $80 \%$ of potassium remained in the straw of oilseed rape, due to its concentration in the stems and leaves and physiological functions. According to Grzebisz [71], plants accumulate potassium mainly in the vegetative organs, which is confirmed in research by other authors [48].

\subsubsection{Calcium and Magnesium}

The calcium content in the seeds during the study showed little variation, ranging from 3.44 to $4.56 \mathrm{~g} \mathrm{Ca} \cdot \mathrm{kg}^{-1}$ (Table S7). On average in the experiment, all sulphur fertilisation treatments increased calcium content in comparison with the control (from $3.51 \mathrm{~g} \mathrm{Ca} \cdot \mathrm{kg}^{-1}$ 
to $3.64-3.88 \mathrm{~g} \mathrm{Ca} \mathrm{kg}^{-1}$ ) (Figure 10a). Its content in the straw was much higher and varied

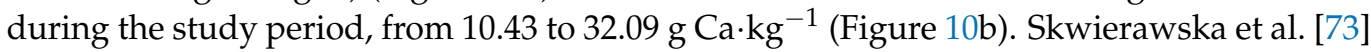
and Brodowska and Kaczor [76] noted an increase in calcium content in the grain of cereals following sulphur application. It should be noted that in 2013, the content of this macroelement in the straw was nearly twice as high as in 2011 and markedly higher than in 2012 (Table S7).

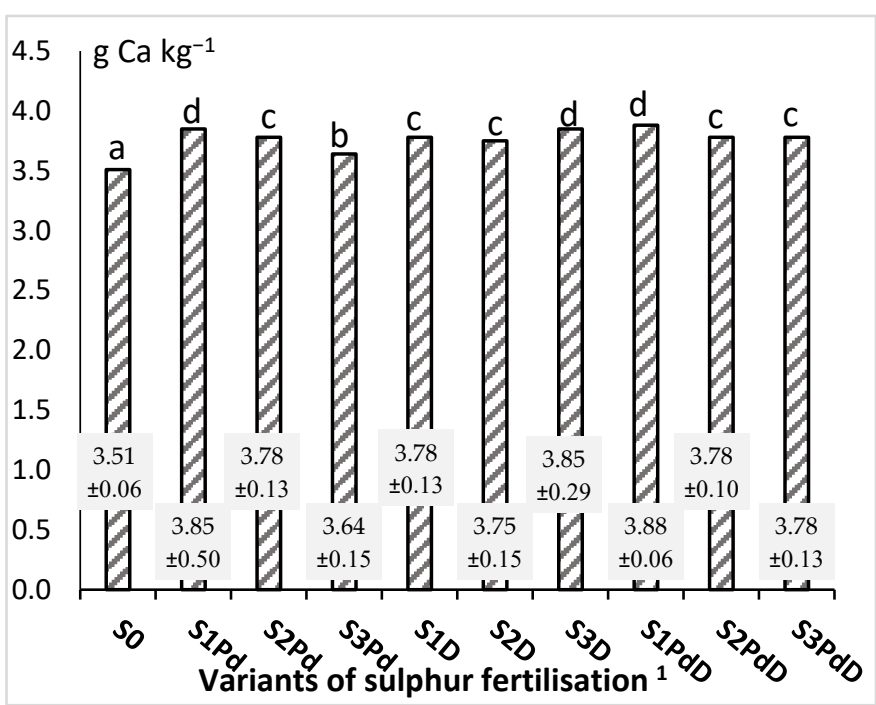

(a)

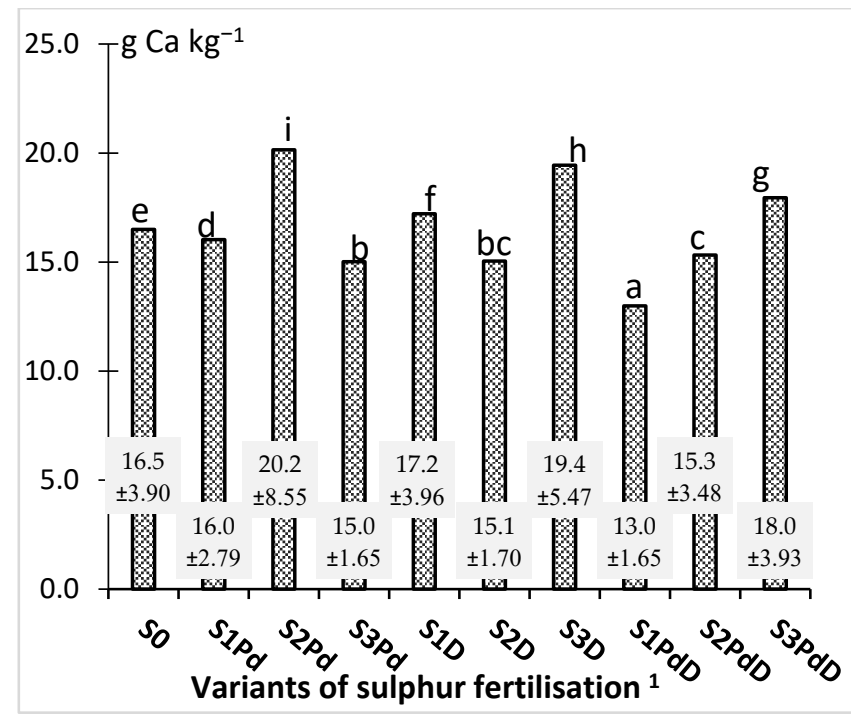

(b)

Figure 10. (a) Calcium content in the rape seeds on average for variants of sulphur fertilisation; (b) Calcium content in the rape straw on average for variants of sulphur fertilisation. ${ }^{1}$ See Table 2 ; Means followed by the same letter are not statistically different at the $\alpha=0.05$ level. \pm -standard deviation.

The magnesium content in the seeds was also varied (Table S8). Sulphur application generally increased the content of this macroelement, but in a narrow range from 2.94 $\mathrm{g} \mathrm{kg}^{-1}$ for the control to $3.04-3.17 \mathrm{~g} \mathrm{~kg}^{-1}$ for the sulphur fertilisation treatments (Figure 11a). In a study by Stepien et al. [69], the magnesium content in rapeseeds ranged from 2.90 to $3.15 \mathrm{~g} \mathrm{~kg}^{-1}$, and differences in the intensity of cultivation technology, including sulphur fertilisation, did not significantly affect magnesium content in the seeds. Jarecki [77] also reported that foliar fertilisation of oilseed rape did not affect the magnesium content in the seeds. Magnesium content in the straw was $1.42 \mathrm{~g} \mathrm{~kg}^{-1}$ and was significantly increased only by foliar application of $60 \mathrm{~kg} \mathrm{~S} \cdot \mathrm{ha}^{-1}$ (Figure 11b). Podleśna [56] reported that foliar feeding with magnesium sulphate resulted in higher content and uptake of magnesium in comparison to soil fertilisation of oilseed rape. The highest magnesium content, however, was noted in the plants that were not fertilised with sulphur, which had very high concentrations of this macroelement in the leaves, stems, and roots. According to the author, the excessive content of magnesium in conditions of sulphur deficiency indicates that it was taken up from the environment but could not be transported or distributed in the plants, because the lack of sulphur inhibited the growth and development of their organs. Thus, a phenomenon opposite to 'dilution' occurred, i.e., the nutrients were 'concentrated' in the reduced mass of the plant. In an experiment by Brodowska and Kaczor [76], the most pronounced increase in magnesium uptake was noted following application of sulphur in the form of sodium sulphate, while elemental sulphur and sodium thiosulphate were not effective. According to the authors, the presence of sulphate ions in the soil was probably conducive to uptake of magnesium ions. 


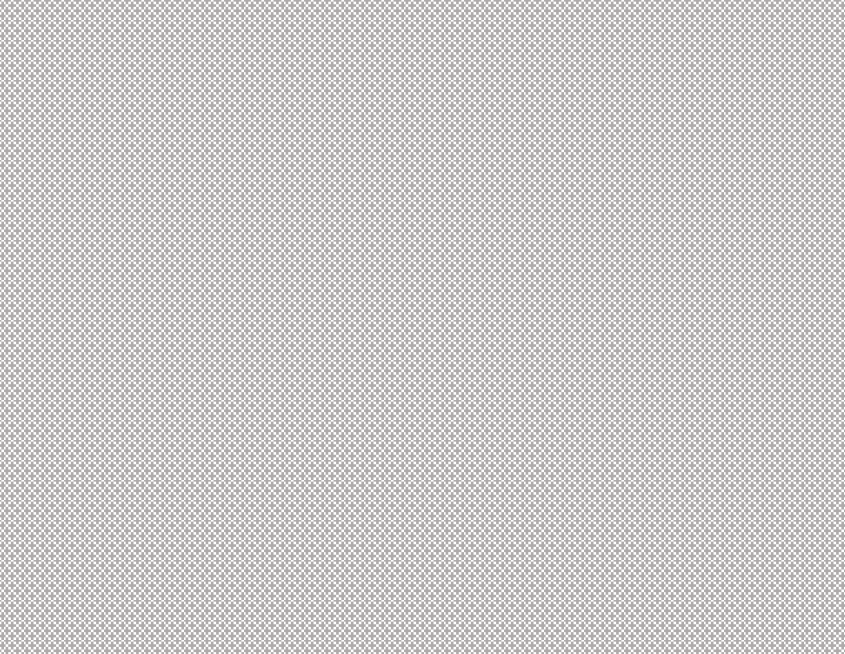

(a)

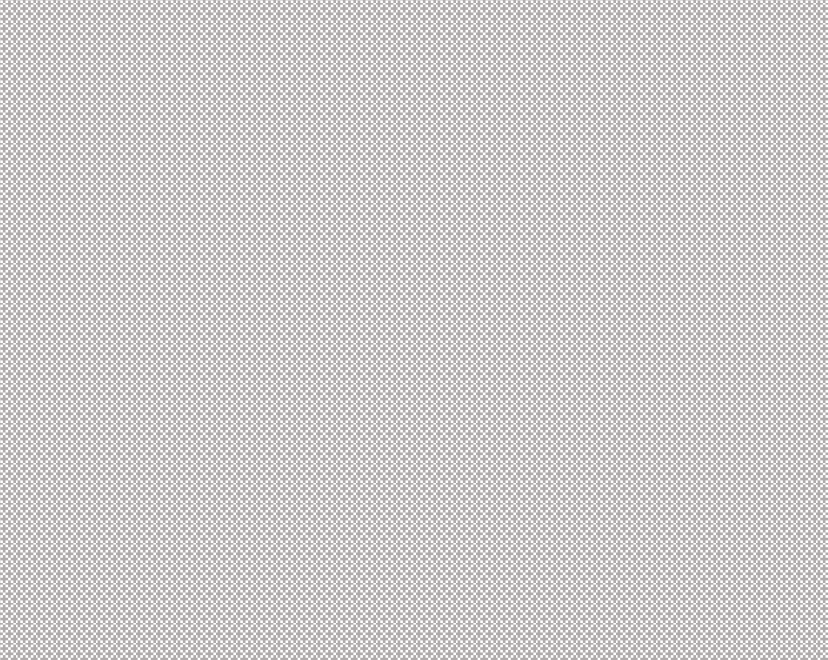

(b)

Figure 11. (a) Magnesium content in the rape seeds on average for variants of sulphur fertilisation; (b) Magnesium content in the rape straw on average for variants of sulphur fertilisation. ${ }^{1}$ See Table 2; Means followed by the same letter are not statistically different at the $\alpha=0.05$ level. \pm -standard deviation.

The harvest index of calcium accumulation ranged from $4.07 \%$ to $13.40 \%$ (Table S9). Foliar application of sulphur decreased the value of the index, while mixed application significantly increased the share of calcium accumulated in the seeds in its total accumulation (Figure 12a). According to Grzebisz [71], calcium accumulates mainly in the pods, and only marginally in the seeds. In a study by Podleśna [19], sulphur fertilisation significantly increased the content and accumulation of calcium in the straw of oilseed rape. The author suggests that this may be linked to greater resistance to certain fungal diseases [78]. A higher concentration of calcium in the cell walls increases the resistance of plants, preventing infection by pathogens by making it more difficult for the enzymes they secrete to macerate the cell wall. It is possible that the positive effect of sulphur fertiliser on the natural immunity of oilseed rape to stress factors, including fungal diseases, may result not only from increased production of sulphur compounds such as glucosinolates or glutathione, but also from morphological changes in the cell wall of the leaves and stems [19].

The harvest index of magnesium accumulation ranged from 33.02\% to $61.33 \%$ (Table S9). Soil application or mixed application of sulphur generally increased its value (Figure 12b). According to Grzebisz [71], distribution of magnesium in the organs of oilseed rape (shoots, pods and seeds) is roughly balanced, with slightly greater accumulation in the seeds, and the magnesium harvest index is 30-40\%. Podleśna [19] reported that sulphur fertilisation did not affect magnesium content in the seeds or straw of rape, but significantly increased its uptake in the biomass of straw. According to the author, 55-57\% of magnesium remained in the straw of rape. 


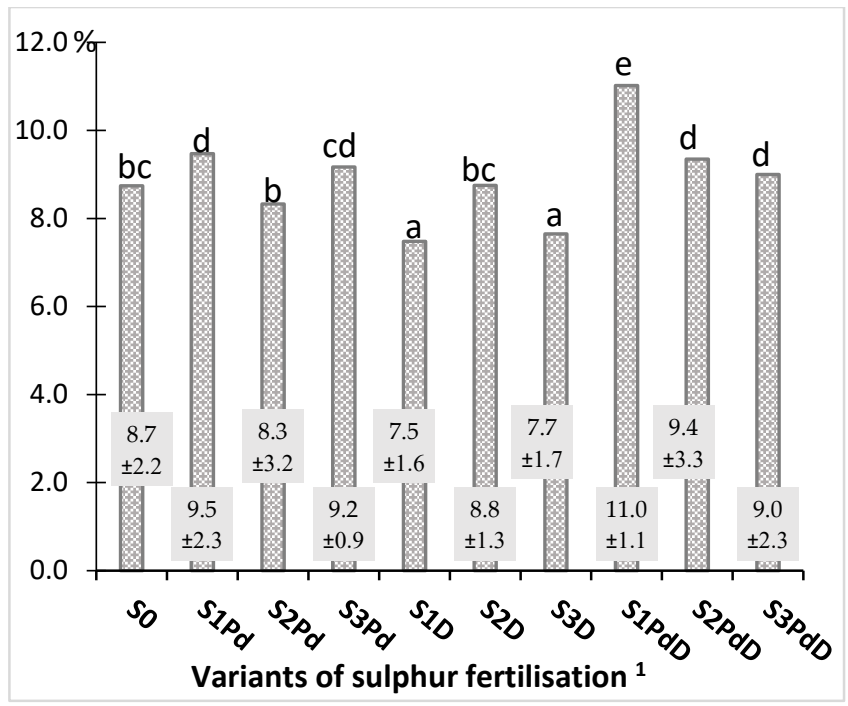

(a)

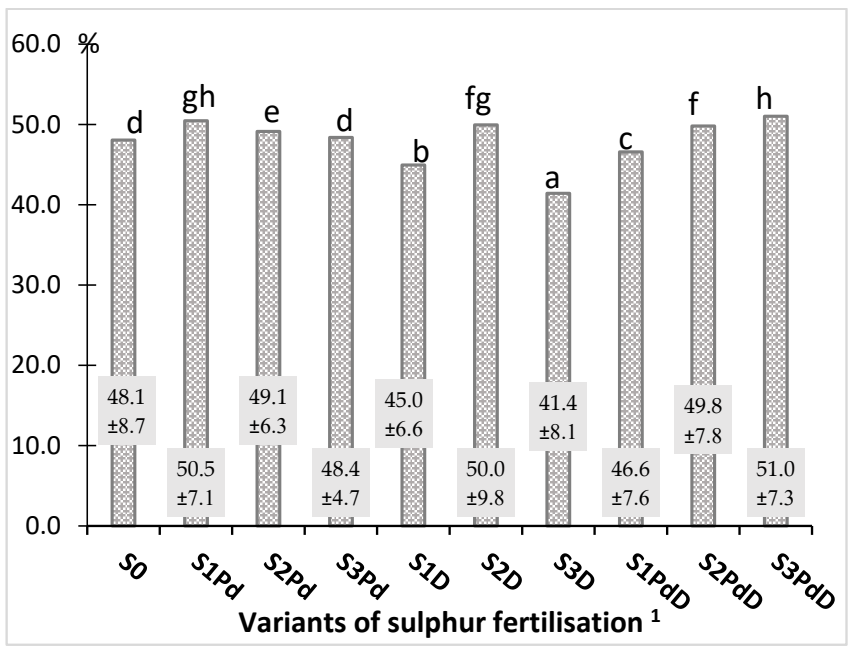

(b)

Figure 12. (a) Calcium harvest index on average for variants of sulphur fertilisation; (b) Magnesium harvest index on average for variants of sulphur fertilisation. ${ }^{1}$ See Table 2; Means followed by the same letter are not statistically different at the $\alpha=0.05$ level. \pm -standard deviation.

\section{Conclusions}

The effect of sulphur on oilseed rape yield significantly depended on the amount and means of sulphur application. Even the lowest level of $20 \mathrm{~kg} \mathrm{~S} \cdot \mathrm{ha}^{-1}$, irrespective of the means of application, significantly increased the seed yield. In the case of autumn soil application and foliar application alone, the differences between the lowest rate and higher ones (40 and $60 \mathrm{~kg} \mathrm{~S} \cdot \mathrm{ha}^{-1}$ ) were not significant. In the case of mixed application, $60 \mathrm{~kg} \mathrm{~S} \cdot \mathrm{ha}^{-1}$ significantly increased yield in comparison with lower application. Sulphur fertilisation also significantly increased the straw yield, with foliar application found to be the most favourable to the development of the vegetative parts.

Sulphur fertilisation affected the mineral composition of rapeseeds. Overall, all sulphur application treatments significantly increased the content of N, P, K, Ca and $\mathrm{Mg}$ in the seeds compared with the control treatment, but the differences were not great. The content of macroelements in the straw was more varied than in the seeds. Sulphur fertilisation increased the content of $\mathrm{S}, \mathrm{P}$ and $\mathrm{K}$ in the vegetative parts, but in the case of nitrogen, calcium, and magnesium, the effect of sulphur application was much smaller. 
Each of the sulphur fertilisation treatments reduced the harvest index of sulphur. Each level of foliar application decreased the harvest index of nitrogen, phosphorus, potassium, and calcium, whereas soil application of $20 \mathrm{~kg} \cdot \mathrm{ha}^{-1}$ and mixed application of 40 and $60 \mathrm{~kg} \cdot \mathrm{ha}^{-1}$ increased the harvest index of phosphorus, potassium and calcium.

Supplementary Materials: The following are available online at https:/ / www.mdpi.com/article/ 10.3390 /agronomy12010068/s1, Table S1. Nitrogen content in rape seeds and straw, mean values for interaction variants of sulphur fertilisation $\times$ years, Table S2. Sulphur content in rape seeds and straw, mean values for interaction variants of sulphur fertilisation $\times$ years, Table S3. Nitrogen and sulphur harvest index, mean values for interaction variants of sulphur fertilisation $\times$ years, Table S4. Phosphorus content in rape seeds and straw, mean values for interaction variants of sulphur fertilisation $\times$ years, Table S5. Potassium content in rape seeds and straw, mean values for interaction variants of sulphur fertilisation $\times$ years, Table S6. Phosphorus and potassium harvest index, mean values for interaction variants of sulphur fertilisation $\times$ years. Table S7. Calcium content in rape seeds and straw, mean values for interaction variants of sulphur fertilisation $\times$ years, Table S8. Magnesium content in rape seeds and straw, mean values for interaction variants of sulphur fertilisation $\times$ years, Table S9. Calcium and magnesium harvest index, mean values for interaction variants of sulphur fertilisation $\times$ years.

Author Contributions: Conceptualization, M.S. and A.G.; methodology, M.S. and A.G., Formal analysis, M.S. and A.G.; writing — original draft preparation, M.S. and A.G. All authors have read and agreed to the published version of the manuscript.

Funding: This research received no external funding.

Data Availability Statement: The data presented in this study are available on request from the corresponding author.

Conflicts of Interest: The authors declare no conflict of interest.

\section{References}

1. Kozłowska-Strawska, J.; Badora, A. Selected problems of sulfur management in crops. Pol. J. Nat. Sci. 2013, 28, 309-316.

2. Barczak, B.; Skinder, Z.; Piotrowski, R. Sulphur as a factor that affects nitrogen effectiveness in spring rapeseed agrotechnics. Part III. Agronomic use efficiency of nitrogen. Acta Sci. Pol. Agric. 2017, 16, 179-189. [CrossRef]

3. Groth, D.A.; Sokólski, M.; Jankowski, K.J. A Multi-criteria evaluation of the effectiveness of nitrogen and sulfur fertilization in different cultivars of winter rapeseed-productivity, economic and energy balance. Energies 2020, 13, 4654. [CrossRef]

4. Marazzi, C.; Städler, E. Influence of plant sulphur nutrition on oviposition and larval performance of the diamondback moth. Entomol. Exp. Appl. 2004, 111, 225-232. [CrossRef]

5. Ahmad, A.; Khan, I.; Anjum, N.A.M.; Diva, I.; Abdin, M.Z.; Iqbal, M. Effect of timing of sulfur fertilizer application on growth and yield of rapeseed. J. Plant Nutr. 2005, 28, 1049-1059. [CrossRef]

6. Barłóg, P.; Grzebisz, W.; Diatta, J. Effect of timing and nitrogen fertilizers on nutrients content and uptake by winter oilseed rape. Part II. Dynamics of nutrients uptake. In Chemistry for Agriculture; Górecki, H., Dobrzański, Z., Kafarski, P., Eds.; Czech-Pol Trade: Prague, Czech Republic; Brussels, Belgium, 2005; Volume 6, pp. 113-123.

7. Jankowski, K.J.; Kijewski, Ł.; Groth, D.; Skwierawska, M.; Budzyński, W.S. The effect of sulfur fertilization on macronutrient concentrations in the post-harvest biomass of rapeseed (Brassica napus L. ssp. oleifera Metzg). J. Elem. 2015, 20, 585-597. [CrossRef]

8. Ahmad, A.; Abdin, M.Z. Interactive effect of sulphur and nitrogen on the oil and protein contents and on the fatty acid profiles of oil in the seeds of rapeseed (Brassica campestris L.) and mustard (Brassica juncea L. Czern. and Coss.). J Agron. Crop Sci. 2000, 185, 49-54. [CrossRef]

9. Rausch, T.; Wachter, A. Sulfur metabolism: A versatile platform for launching defense operations. Trends Plant Sci. 2005, 10, 503-509. [CrossRef]

10. Farahbakhsh, H.; Pakgohar, N.; Karimi, A. Effects of nitrogen and sulphur fertilizers on yield, yield components and oil content of oilseed rape (Brassica napus L.). Asian J. Plant Sci. 2006, 5, 112-115.

11. Jankowski, K.J.; Budzyński, W.; Szymanowski, A. Influence of the rate and timing of sulphur fertilization on winter oilseed rape yield. Rośliny Oleiste Oilseed Crops 2008, XXIX, 76-90.

12. Egesel, C.Ö.; Gül, M.K.; Kahrıman, F. Changes in yield and seed quality traits in rapeseed genotypes by sulphur fertilization. Eur. Food Res. Technol. 2009, 229, 505-513. [CrossRef]

13. Brennan, R.F.; Bell, R.W.; Raphael, C.; Eslick, H. Sources of sulfur for dry matter, seed yield, and oil concentration of canola grown in sulfur deficient soils of south-western Australia. J. Plant Nutr. 2010, 33, 1180-1194. [CrossRef]

14. Begum, F.; Hossain, F.; Mondal, M.d.R.I. Influence of sulphur on morpho-physiological and yield parameters of rapeseed (Brassica campestris L.). Bangladesh J. Agric. Res. 2012, 37, 645-652. [CrossRef] 
15. Dash, N.R.; Ghosh, G.K. Efficacy of gypsum and magnesium sulfate as sources of sulfur to rapeseed in lateritic soils. J. Plant Nutr. 2012, 35, 2156-2166. [CrossRef]

16. Sienkiewicz-Cholewa, U.; Kieloch, R. Effect of sulphur and micronutrients fertilization on yield and fat content in winter rape seeds (Brassica napus L.). Plant Soil Environ. 2015, 61, 164-170. [CrossRef]

17. Chwil., S. The effect of foliar feeding under different soil fertilization conditions on the yield structure and quality of winter oilseed rape (Brassica napus L.). Electron. J. Pol. Agric. Univ. 2016, 19, 2.

18. Tuncturk, R.; Tuncturk, M. The effect of different sulphur doses on the yield and quality of rapeseed (Brassica napus L.). Fresenius Environ. Bull. 2017, 26, 6952-6957.

19. Podleśna, A. The effect of sulfur fertilization on concentration and uptake of nutrients by winter oilseed rape. (Wpływ nawożenia siarką na zawartość i pobieranie składników pokarmowych przez rzepak ozimy). Rośliny Oleiste Oilseed Crops 2004, XXV, 627-636.

20. Kaczor, A.; Brodowska, M. Effect of liming and sulphur fertilization on the growth and yielding of spring forms of wheat and rape. Part II. Rape. (Wpływ wapnowania i nawożenia siarką na wzrost, rozwój i plonowanie form jarych pszenicy i rzepaku. Cz. II. Rzepak). Acta Agrophys. 2003, 1, 661-666.

21. Cui, Y.; Wang, Q.; Dong, Y.; Li, H.; Christie, P. Enhanced uptake of soil Pb and Zn by Indian mustard and winter wheat following combined soil application of elemental sulphur and EDTA. Plant Soil 2004, 261, 181-188. [CrossRef]

22. Jankowski, K.; Kijewski, Ł.; Skwierawska, M.; Krzebietke, S.; Mackiewicz-Walec, E. Effect of sulfur fertilization on the concentrations of copper, zinc and manganese in the roots, straw and oil cake of rapeseed (Brassica napus L. ssp oleifera Metzg). J. Elem. 2014, 19, 433-446. [CrossRef]

23. Lošák, T.; Hrivna, L.; Richter, R. Effect of increasing doses of nitrogen and sulphur on yields, quality and chemical composition of winter rape. Zesz. Probl. Post. Nauk. Rol. 2000, 472, 481-487.

24. McGrath, S.P.; Zhao, F.J. Sulphur uptake, yield responses and the interactions between nitrogen and sulphur in winter oilseed rape (Brassica napus). J. Agric. Sci. 1996, 126, 53-62. [CrossRef]

25. WRB. IUSS Working Group. World Reference Base for Soil Resources 2014, update 2015 International soil classification system for naming soils and creating legends for soil maps. In World Soil Resources Reports; FAO: Rome, Italy, 2014; No. 106. 201.

26. The Polish Committee for Standarization. PKN Polish Standard PN-ISO 10390. In Soil Quality-Determination of pH. PKN; The Polish Committee for Standarization: Warszawa, Poland, 1997.

27. Anonymous. Catalog of Research Methods at Chemical and Agricultural Stations; Regional Chemical and Agricultural Station in Lublin: Lublin, Poland, 2010.

28. The Polish Committee for Standarization. PKN Polish Standard PN-R-04023. In Chemical and Agricultural Analysis of SoilDetermination of Available Phosphorus in Mineral Soils; PKN: Warszawa, Poland, 1996.

29. The Polish Committee for Standarization. PKN Polish Standard PN-R-04022. In Chemical and Agricultural Analysis of SoilDetermination of Available Potassium in Mineral Soils; PKN: Warszawa, Poland, 1996.

30. The Polish Committee for Standarization. PKN Polish Standard PN-R-04020:1994/Az1. In Chemical and Agricultural Analysis of soil-Determination of Available Magnesium Content; PKN: Warszawa, Poland, 2004.

31. Lancashire, P.D.; Bleiholder, H.; Van den Boom, T.; Langelüddeke, P.; Strauss, R.; Weber, E.; Witzenberger, A. A uniform decimal code for growth stages of crops and weeds. Ann. Appl. Biol. 1991, 119, 561-601. [CrossRef]

32. Available online: Databaseofplantprotectionproducts.www.ior.poznan.pl (accessed on 30 November 2021).

33. Kapuściński, J.; Nowak, R. The frequency of the occurrence of droughts and post-droughts periods in mid-west Poland on the example of Poznań, Wałcz and Wieluń. In Kształtowanie i ochrona środowiska leśnego; Miler, A., Ed.; Klimat a las. Wyd. AR: Poznań, Poland, 2003; pp. 76-88.

34. Skowera, B.; Jędrszczyk, E.; Kopcińska, J.; Ambroszczyk, A.M.; Kołtun, A. The effects of hydrothermal conditions during vegetation period on fruit quality of processing tomatoes. Pol. J. Environ. Stud. 2014, 23, 195-202.

35. Kamińska, W.; Kardasz, T.; Strahl, A. Metody badań laboratoryjnych w stacjach chemiczno-rolniczych. Część 2. Badanie materiału roślinnego. In Laboratory Test Methods in Chemical and Agricultural Stations. Part 2. Examination of Plant Material. Wyd.; IUNG: Puławy, Poland, 1981.

36. Zając, T.; Klimek-Kopyra, A.; Oleksy, A.; Lorenc-Kozik, A.; Ratajczak, K. Analysis of yield and plant traits of oilseed rape (Brassica napus L.) cultivated in temperate region in light of the possibilities of sowing in arid areas. Acta Agrobot. 2016, 69, 1-13. [CrossRef]

37. Brachaczek, A.; Kaczmarek, J.; Jędryczka, M. Warm and wet autumns favour yield losses of oilseed rape caused by phoma stem canker. Agronomy 2021, 11, 1171. [CrossRef]

38. Marjanović-Jeromela, A.; Terzić, S.; Jankulovska, M.; Zorić, M.; Kondić-Špika, A.; Jocković, M.; Hristov, N.; Crnobarac, J.; Nagl, N. Dissection of year related climatic variables and their effect on winter rapeseed (Brassica napus L.) development and yield. Agronomy 2019, 9, 517. [CrossRef]

39. Jarecki, W. The size and quality of winter rape seed yield depending on the cultivar type. Agron. Sci. 2021, LXXVI, 5-14. [CrossRef]

40. Wielebski, F. Share of yield components in the creation of yield of winter oilseed rape hybrids. (Udział elementów struktury plonu w kształtowaniu plonu nasion mieszańcowych odmian rzepaku ozimego). Rośliny Oleiste Oilseed Crops 2005, XXVI, 87-98.

41. Stępień, A.; Wojtkowiak, K.; Pietrzak-Fiećko, R. Nutrient content, fat yield and fatty acid profile of winter rapeseed (Brassica napus L.) grown under different agricultural production systems. Chil. J. Agric. Res. 2017, 77, 266-277. [CrossRef] 
42. Cwalina-Ambroziak, B.; Stępień, A.; Kurowski, T.P.; Głosek-Sobieraj, M.; Wiktorski, A. The health status and yield of winter rapeseed (Brassica napus L.) grown in monoculture and in crop rotation under different agricultural production systems. Arch. Agron. Soil Sci. 2016, 62, 1722-1732. [CrossRef]

43. Hegewald, H.; Koblenz, B.; Wensch-Dorendorf, M.; Christen, O. Impacts of high intensity crop rotation and N management on oilseed rape productivity in Germany. Crop Pasture Sci. 2016, 67, 439-449. [CrossRef]

44. Różyło, K.; Pałys, E. Influence of crop rotation and row spacing on weed infestation of winter rape grown on rendzina soil. Acta Sci. Pol. Agric. 2011, 10, 57-64.

45. Sieling, K.; Christen, O.; Nemati, B.; Hanus, H. Effects of previous cropping on seed yield and yield components of oil-seed rape (Brassica napus L.). Eur. J. Agron. 1997, 6, 215-223. [CrossRef]

46. Jaskulska, I.; Jaskulski, D.; Kotwica, K.; Piekarczyk, M.; Wasilewski, P. Yielding of winter rapeseed depending on the forecrops and soil tillage methods. (Plonowanie rzepaku ozimego w zależności od przedplonów i sposobów uprawy roli). Ann. UMSC Sec. Agric. 2014, 69, 30-38.

47. Jankowski, K.J.; Budzyński, W.; Szymanowski, A. Effect of sulfur on the quality of winter rape seeds. J. Elem. 2008, 13, 521-534.

48. Jakubus, M.; Toboła, P. Content of total and sulphate sulphur in winter oilseed rape depending on fertilization. (Zawartość siarki ogólnej i siarczanowej w rzepaku ozimym w zależności od nawożenia). Rośliny Oleiste Oilseed Crops 2005, XXIV, 149-162.

49. Wielebski, F.; Wójtowicz, M. Effect of spring sulphur fertilization on yield and glucosinolate content in seeds of winter oilseed rape composite hybrids. (Wpływ wiosennego nawożenia siarką na plon i zawartość glukozynolanów w nasionach odmian mieszańcowych złożonych rzepaku ozimego). Rośliny Oleiste Oilseed Crops 2003, XXIV, 109-119.

50. Gallejones, P.; Castellón, A.; del Prado, A.; Unamunzaga, O.; Aizpurua, A. Nitrogen and sulphur fertilization effect on leaching losses, nutrient balance and plant quality in a wheat-rapeseed rotation under a humid Mediterranean climate. Nutr. Cycl. Agroecosyst. 2012, 93, 337-355. [CrossRef]

51. Wielebski, F. The effect of sulphur fertilization on the yield of different breeding forms of winter oilseed rape in the conditions of diverse nitrogen rates. (Wpływ nawożenia siarką w warunkach stosowania zróżnicowanych dawek azotu na plonowanie różnych typów odmian rzepaku ozimego). Rośliny Oleiste-Oilseed Crops 2011, XXXII, 61-78.

52. Zhao, F.J.; Evans, E.J.; Bilsborrow, P.E. Varietal differences in sulphur uptake and utilization in relation to glucosinolate accumulation in oilseed rape. In Proceedings of the 9th International Rapeseed Congress, Cambridge, UK, 4-7 July 1995; Volume 1, pp. 271-273.

53. Withers, P.J.A.; Zhao, F.J.; McGrath, S.P.; Evans, E.J.; Sinclair, A.H. Sulphur inputs for optimum yields of cereals. Asp. Appl. Biol. 1997, 50, 191-197.

54. Janzen, H.H.; Bettany, J.R. Sulfur nutrition of rapeseed. II. Effect of time of sulfur application. Soil Sci. Soc. Am. J. 1984, 48, 107-112. [CrossRef]

55. Grant, C.A.; Mahli, S.S.; Karamanos, R.E. Sulfur management for rapeseed. Field Crops Res. 2012, 128, 119-128. [CrossRef]

56. Podleśna, A. The effect of soil and foliar application of sulfur on the yield and mineral composition of winter oilseed rape plants. (Wpływ doglebowego i dolistnego stosowania siarki na plon i skład mineralny roślin rzepaku ozimego). Ann. UMCS Sec. E 2009, LXIV, 68-75.

57. Phillips, S.B.; Mullins, G.L. Foliar burn and wheat grain yield responses following topdress-applied nitrogen and sulphur fertilizers. J. Plant Nutr. 2004, 27, 921-930. [CrossRef]

58. Zhao, F.J.; McGrath, S.P.; Blake-Kalff, M.M.A.; Link, A.; Tucker, M. Crop response to sulphur fertilization in Europe. Nawozy I Nawożenie-Fertil. Fertil. 2003, 3, 26-51.

59. Booth, E.J.; Batchelor, S.E.; Walker, K.C. The effect of foliar applied sulphur on individual glukosinolates in oilseed rape seed. J. Plant. Nutr. Soil Sci. 1995, 158, 87-88. [CrossRef]

60. Heneklaus, S.; Bloem, E.; Schnug, E. Sulphur in agroecosystems. Folia Univ. Agric. Stetin. 2000, 204, 17-32.

61. Fismes, J.; Vong, P.C.; Guckert, A.; Frossard, E. Influence of sulfur on apparent N-use efficiency, yield and quality of oilseed rape (Brassica napus L.) grown on a calcareous soil. Eur. J. Agron. 2000, 12, 127-141. [CrossRef]

62. Dłużniewska, J.; Nadolnik, M.; Kulig, B. Fungal diseases of winter oilseed rape under the different level of nitrogen and sulphur fertilization. (Choroby rzepaku ozimego w zależności od poziomu zaopatrzenia roślin w azot i siarke). Prog. Plant Protect. Post. Ochr. Roś. 2011, 51, 1811-1815.

63. Kurowski, T.; Majchrzak, B.; Jankowski, K. Effect of sulfur fertilization on the sanitary state of plants of the family Brassicaceae Acta Agrobot. 2010, 63, 171-178. [CrossRef]

64. De Kok, L.J.; Castro, A.; Durenkamp, M.; Stuiver, C.E.; Westerman, S.; Yang, L.; Stulen, I. Sulphur in plant phisiology. Nawozy I Nawożenie-Fertil. Fertil. 2003, 2, 55-80.

65. Anjum, N.A.; Gill, S.S.; Umar, S.; Ahmad, I.; Duarte, A.C.; Pereira, E. Improving growth and productivity of oleiferous Brassicas under changing environment: Significance of nitrogen and sulphur nutrition, and underlying mechanisms. Sci. World J. 2012, 657808. [CrossRef]

66. Eriksen, J.; Nielsen, M.; Mortensen, J.V.; Schjorring, J.K. Redistribution of sulphur during generative growth of barley plants with different sulphur and nitrogen status. Plant Soil 2001, 230, 239-246. [CrossRef]

67. Jan, A.; Ahmad, G.; Arif, M.; Jan, M.T.; Marwat, K.B. Quality parameters of canola as affected by nitrogen and sulfur fertilization. J. Plant Nutr. 2010, 33, 381-390. [CrossRef] 
68. Barczak, B.; Barczak, T.; Skinder, Z.; Piotrowski, R. Proportions of nitrogen and sulphur in spring rapeseeds depending on fertilization with these elements. J. Elem. 2020, 25, 1385-1398. [CrossRef]

69. Stępień, A.; Wojtkowiak, K.; Pietrzak-Fiećko, R. Influence of a crop rotation system and agrotechnology level on the yielding and seed quality of winter rapeseed (Brassica napus L.) varieties Castille and Nelson. J. Elem. 2018, 23, 1281-1293. [CrossRef]

70. Skwierawska, M.; Benedycka, Z.; Jankowski, K.; Skwierawski, A. Sulphur as a fertiliser component determining crop yield and quality. J. Elem. 2016, 21, 609-623. [CrossRef]

71. Grzebisz, W. Technologie nawożenia roślin uprawnych-fizjologia plonowania. In Tom 1. Oleiste, Okopowe i Strączkowe; PWRiL: Poznań, Poland, 2011; p. 413.

72. Barczak, B.; Knapowski, T.; Kozera, W.; Ralcewicz, M. Effects of sulphur fertilisation on the content and uptake of macroelements in narrow-leaf lupin. Rom. Agric. Res. 2014, 31, 245-251.

73. Skwierawska, M.; Zawartka, L.; Zawadzki, B. The effect of different rates and forms of applied sulphur on nutrient composition of planted crops. Plant Soil Environ. 2008, 54, 179-189. [CrossRef]

74. Majumder, S.; Halder, T.K.; Saha, D. Integrated nutrient management of rapeseed (Brassica campestris L. var. yellow sarson) grown in a typic haplaquept soil. J. Nat. Appl. Sci. 2017, 9, 1151-1156. [CrossRef]

75. Szczepanek, M.; Siwik-Ziomek, A. P and K accumulation by rapeseed as affected by biostimulant under different NPK and S fertilization doses. Agronomy 2019, 9, 477. [CrossRef]

76. Brodowska, M.; Kaczor, A. The effect of various forms of sulphur and nitrogen on calcium and magnesium content and uptake in spring wheat (Triticum aestivum L.) and cocksfoot (Dactylis glomerata L.). J. Elem. 2009, 14, 641-647. [CrossRef]

77. Jarecki, W. The reaction of winter oilseed rape to different foliar fertilization with macro- and micronutrients. Agriculture 2021, 11, 515. [CrossRef]

78. Sadowski, C.z.; Baturo, A.; Lenc, L.; Trzciński, J. Downy mildew (P. parasitica) and powdery mildew (E. cruciferarum) occurrence on spring oilseed rape cv. Star depending on differentiated fertilisation with nitrogen and sulphur. (Występowanie mączniaka rzekomego (Perono-spora parasitica/Pers.ex Fr./Fr.) i mączniaka prawdziwego (Erysiphe crucifererum Opiz ex L. Junell) na rzepaku jarym odmiany Star przy zróżnicowanym nawożeniu azotem i siarką). Rośliny Oleiste Oilseed Crops 2002, XXIII, $391-408$. 